\title{
PREGLEDNI ČLANCI
}

UDK: 343.85:343.57-053.6(497.6)

doi: $10.5937 /$ crimen $2003272 \mathrm{O}$

PREGLEDNI ČLANAK

PRIMLJEN / PRIHVAĆEN: 23.10.2020. / 23.11.2020.

\author{
Suad Orlic* \\ Univerzitet u Zenici \\ Sadmir Karovic ** \\ Pravni fakultet, Univerzitet u Travniku
}

\section{KAZNENOPRAVNA ZAŠTITA MALOLJETNIH LICA OD ALKOHOLIZMA U BOSNI I HERCEGOVINI}

\begin{abstract}
Apstrakt: Alkoholizam, odnosno zloupotreba alkohola i odavanje maloljetnih lica alkoholu je jedna od najzastupljenijih asocijalnih pojava kod maloljetnih lica i jedan od glavnih uzročnika njihovog delinkventnog ponašanja. Naime, sve je izraženija tendencija učestale zloupotrebe i konzumiranja alkohola, odnosno odavanja maloljetnih lica alkoholu, kao i incidenca činjenja kaznenih djela pod uticajem alkohola. U radu su elaborirani kaznenopravni aspekti zaštite maloljetnih lica od alkoholizma, odnosno zloupotrebe alkohola maloljetnih lica i ukazano na problematiku neujednačene i neadekvatne zakonske, odnosno kazneno pravne regulative u Bosni i Hercegovini, te dati odgovarajući prijedlozi izmjena postojećih rješenja u cilju postizanja bolje i efikasnije kaznenopravne zaštite maloljetnih lica od zloupotrebe alkohola.
\end{abstract}

Ključne riječi: krivičnopravna zaštita, prekršajnopravna zaštita, maloljetna lica, odavanje alkoholu.

\section{UVODNO O ALKOHOLIZMU}

U posljednjih nekoliko decenija u svijetu, sa naročitim naglaskom na tranzicijske zemlje u koje se ubraja i Bosna i Hercegovina, sve je izraženiji problem alkoholizma, odnosno zloupotrebe alkohola, pri čemu je taj problem naročito izražen kod maloljetnih lica. ${ }^{1}$

\footnotetext{
* Docent na krivičnopravnoj katedri na Univerzitetu u Zenici, Zaposlen u Ministarstvu unutrašnjih poslova Zeničko-dobojskog kantona, suad.orlic@gmail.com.

** Vanredni profesor na krivičnopravnoj katedri na Pravnom fakultetu Univerziteta u Travniku, Zaposlen u Državnoj agenciji za istrage i zaštitu, Bosna i Hercegovina, karovic.s@hotmail.com.

1 U krivičnim zakonodavstvima u Bosni i Hercegovini, odnosno u entitetskim i krivičnom zakonodavstvu $\mathrm{BD} \mathrm{BiH}$ prisutan je problem neujednačene pravne terminologije za pojam „djeteta“, odnosno „maloljetnika“, tako da ovi pojmovi imaju različito značenje u krivičnom pravu $\mathrm{BiH}$, odnosno nemaju isto značenje u krivičnim zakonima. Ta razlika se ogleda u tome što u krivič-
} 


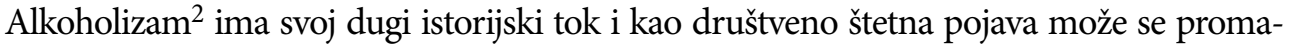
trati i definisati sa više aspekata, odnosno može se promatrati kao socio-medicinski problem, zatim kao asocijalna, odnosno sociopatološka pojava i kao kriminogeni faktor.

Svjetska zdravstvena organizacija je definisala alkoholizam kao socijalno-medicinski problem koji nastaje zbog zloupotrebe alkoholnih pića u tolikoj mjeri da osoba koja pije zbog toga zapada u zdravstvene i druge probleme, a stvara probleme i sredini u kojoj živi. ${ }^{3}$

Alkoholizam je i pojava asocijalnog ponašanja maloljetnika koja ima veoma teške posljedice na zdravlje maloljetnog lica, porodicu i pojedinca. ${ }^{4}$. Alkoholizam, odnosno konzumiranje alkohola je i kriminogeni faktor koji ima velikog uticaja i na pojavu prestupničkog ponašanja maloljetnih lica, tako da se u literaturi permanentno naglašava veliki uticaj zloupotrebe alkohola na porast maloljetničkog prestu-

nom zakonodavstvu entiteta Republika Srpska, pojam „dijete“ ima šire značenje, tako da prema članu 123. st. 1. tač. 7. „dijete“ kao žrtva krivičnog djela je lice koje nije navršilo osamnaest godina, dok u krivičnom zakonodavstvu entiteta Federacija $\mathrm{BiH}$ i KZ BD BiH pojam „dijete“ ima uže značenje, jer prema čl. 2. st. 12. KZ FBiH i čl. 2. st. $13 \mathrm{KZ} \mathrm{BD} \mathrm{BiH} \mathrm{„dijete“} \mathrm{je} \mathrm{lice} \mathrm{koje} \mathrm{nije} \mathrm{navršilo}$ četrnaest godina, dok je „maloljetnik“, prema članu 2.st.13. KZ FBiH i čl.2.st.14. KZ BD BiH, lice koje nije navršilo osamnaest godina. Pojam djeteta u KZ entiteta RS je usklađen terminologiji Konvencije UN o pravima djeteta iz 1989. kao najvažnijeg i najsveobuhvatnijeg dokumenta za zaštitu prava djece (isti pojam djeteta je propisan i u KZ R. Hrvatske, čl. 87. st. 7). Pojam maloljetnika u KZ entiteta Federacija $\mathrm{BiH}$ i KZ BD BiH je formulacijski neprecizan jer umjesto lica koje je navršilo četrnaest a nije navršilo osamnaest godina (vid. čl. 112. st. 9. KZ R. Srbije), označava lice koje nije navršilo 18 godina (čl. 2. st. 13. KZ FBiH i čl. 2. st. 14. KZ BD BiH) što dovodi do preklapanja sa pojmom maloljetnog lica koji je kao genusni pojam propisan u pojedinim susjednim zakonodavstvima (takav pojam je propisan u Srbiji, čl. 112. st. $10 \mathrm{KZ}$ R. Srbije). Kada je u pitanju prekršajno zakonodavstvo, u oba entitetska i prekršajnom zakonodavstvu BD BiH koristi se isti pojam "maloljetnik" propisivanjem odredbi o maloljetnicima (čl. 40. i 41. ZP entiteta FBiH, čl. 73. ZP entiteta RS, čl. 25 i 26 . ZP BD BiH) uz podjelu maloljetnika na mlađe i starije maloljetnike u ZP FBiH i BD BiH. Radi neujednačene pravne terminologije za pojam "dijete", odnosno „maloljetnik“ $\mathrm{u}$ entitetskim i krivičnom zakonodavstvu $\mathrm{BD} \mathrm{BiH}$, u većem dijelu teksta koji se odnosi na krivičnopravnu zaštitu, u radu će u tehničkom smislu za pojmove „dijete" ili „maloljetnik“, umjesto pojma „mladi“ (koji bi bio neadekvatan zbog svog preširokog značenja i obuhvatanja i kategorije mlađih punoljetnih lica, kao kategorije lica iznad 18 godina starosti) biti korišten pojam „maloljetna lica“ kao lica koja nisu navršila 18 godina života, uz zadržavanje u nazivu inkriminacija i manjem tekstu rada pojmova „dijete“ ili „maloljetnik“ kako su i propisani u inkriminacijama obrađenim u ovom radu, dok će se u radu koji se odnosi na prekršajnopravnu zaštitu koristiti pojam „maloljetnik“.

2 Prema broju oboljelih i umrlih u svijetu, alkoholizam se nalazi na trećem mjestu, iza kardiovaskularnih i malignih oboljenja. Tri do pet posto ukupne svjetske populacije, odnosno $10-15 \%$ punoljetnog svjetskog stanovništva (10\% muškaraca i 3.5\% žena) zavisno je od alkohola. U bivšoj Jugoslaviji sa 24 miliona stanovnika, bilo je oko milion alkoholičara $(4,2 \%)$, pri čemu je odnos konzumiranja alkohola od strane žena i muškaraca bio 1:8 u korist muškaraca (više je muškaraca alkoholičara). Jevreji su najčešći konzumenti, ali sa najmanje problema sa alkoholom, dok u muslimanskim zemljama, zbog uticaja vjere, skoro da i nema alkoholizma. Prema Ledermanovoj statističko-epidemiološkoj teoriji, broj alkoholičara je u proporciji sa srednjom godišnjom potrošnjom alkohola (preračunato u čist alkohol), po glavi stanovnika (vid. M. Munjiza /2017/: Psihopatologija svakodnevnog života, Vodič za zdrave i bolesne, za roditelje i njihovu decu, Treće izdanje, Službeni Glasnik, Beograd, p. 225).

3 H. Šarić /2008/: Prostitucija i ostali oblici socijalne patologije, Tuzla, p.132.

4 N. Karić /2017/: Socijalni rad i maloljetnička delinkvencija u zajednici, Tuzla, p.120. 
pništva. Naime, sve je češća upotreba alkohola kod maloljetnih lica zbog čega je sve veći broj maloljetnih izvršilaca prekršajnih i krivičnih djela. ${ }^{5}$

Prema nekim autorima, alkoholizam ima široko značenje, tako da pored zavisnosti od alkohola, obuhvata i zloupotrebu alkohola. ${ }^{6}$

Značenje alkoholizma tokom 20 vijeka značajno je evoluiralo. Naime, polovinom 20 vijeka alkoholizam se prvobitno dovodio u vezu sa pojavom zavisnosti, tako da je prema definiciji Svjetske zdravstvene organizacije od 1951. godine alkoholizam podrazumijevao ekscesivno uživanje alkoholnih pića koje postepeno dovodi do pojave zavisnosti. Već krajem dvadesetog vijeka, odnosno 1992. godine dolazi do promjene u percepciji shvatanja značenja alkoholizma tako da je u 10. Međunarodnoj klasifikaciji mentalnih poremećaja i poremaćaja ponašanja termin alkoholizam potisnut u drugi plan, pri čemu je dotadašnji termin alkoholizam uvršten u grupu mentalnih poremećaja i poremećaja ponašanja nastalih zbog upotrebe psihoaktivnih supstanci ${ }^{7}$ (u koje se ubraja i alkohol) i u kategorije poremećaja kao što su akutna intoksikacija, zloupotreba/štetna upotreba i sindrom zavisnosti.

Suština alkoholizma, odnosno zloupotrebe alkohola i konzumiranja alkoholnog pića jeste u tome što pad „socijalnih kočnica“ dovodi alkoholizirane ljude u sukob sa okolinom i izaziva brojne prestupe normi za ponašanje, od prekršajnog prestupništva, odnosno od remećenja javnog reda i mira, do krivičnog prestupništva, odnosno činjenja (teških) krivičnih djela što je specifično i svojstveno i maloljetnim licima.

U vezi navedenog, danas je sve više maloljetnih lica koji sve više i učestalije konzumiraju alkohol pri čemu ih konzumiranje alkohola, u znatnoj mjeri, predisponira za prestupničko ponašanje. ${ }^{8} \mathrm{U}$ tom smislu, raširenost upotrebe alkohola $\mathrm{i}$ njegova laka dostupnost putem kupovine pogoduje njegovom konzumiranju i od maloljetnih lica, pogotovo onih koji egzistiraju u disharmoničnim porodicama, gdje je obrazac konzumiranja alkohola preuzet od roditelja.

Uticaj zloupotrebe, odnosno konzumiranja alkohola na pojavu prestupničkog ponašanja maloljetnih lica je značajan, ali je manji u odnosu na uticaj zloupotrebe, odnosno konzumiranja opojnih droga. Naime, novija provedena istraživanja uticaja alkohola i droga na pojavu prestupničkog ponašanja maloljetnih lica ${ }^{9}$ ukazuju da su maloljetna lica danas mnogo više sklona zloupotrebama, odnosno konzumiranju opojnih droga, tako da se mnogo više drogiraju nego što se opijaju alkoholnim pićima, te je i njihova prestupnička aktivnost u mnogo većem procentu uzrokovana odlučujućim uticajem droga u odnosu na činjenje krivičnih djela pod uticajem alkohola.

5 S. Loga /1999/: Sudska psihopatologija, Fakultet kriminalističkih nauka, Sarajevo, p.73.

6 S. Loga: ibid., p. 72.

7 P. Jovanović, S. Čurčić, V. Milosavčević /2000/: Prilog definiciji alkoholizma, Psihijatrijski dani, Vrnjačka banja, p. 106, dostupno na: https://scindex-clanci.ceon.rs/data/pdf/03502538/2000/0350-25380002105J.pdf\#search=\%22prilog\%20definiciji\%20alkoholizma\%22.

8 Z. Nikolić, I. Joksić /2011/: Maloljetnička delinkvencija, krivičnopravni i socijalno-psihološki aspekt, Institut za kriminološka i sociološka istraživanja, Beograd, p. 73.

9 J. Hasić /2017/: Odnos kvaliteta života i delinkventnog ponašanja mladih, Neobjavljeni magistarski rad, Zenica, p. 90. 
To, ni u kom slučaju, ne znači da alkohol nije značajan kriminogeni faktor, odnosno faktor maloljetničkog prestupništva, već da je u manjoj mjeri kauzalno povezan sa prestupničkim ponašanjem maloljetnih lica u odnosu na opojne droge. Naprotiv, mnoga istraživanja pokazuju uticaj alkohola, odnosno konzumiranja alkoholnih pića na prestupničko ponašanje mladih, te da su, $\mathrm{u}$ zavisnosti od psihoaktivnih supstanci, odnosno narkotika i alkohola, glavni prediktori maloljetničkog prestupništva. ${ }^{10}$

\section{PREVENCIJA ALKOHOLIZMA MALOLJETNIH LICA}

Alkoholizam, odnosno zloupotreba alkohola i njegovo konzumiranje kao društveni fenomen i realitet u svakodnevnom životu zavređuje posebnu pažnju kada su u pitanju maloljetna lica, uvažavajući njihovu starosnu dob, s obzirom na njegovo negativno (sa)djelovanje i povezanost sa drugim sociopatološkim pojavama (narkomanija, kocka, prosjačenje, prostitucija i dr).

U zavisnosti od društvenog okruženja i ambijenta na određenom lokalnom području, prije svega i zavisi shvatanje pojave konzumiranja alkohola od strane maloljetnih lica koji kao konzumenti najčešće smatraju da je to društveno prihvatljivo pa i poželjno ponašanje kompatibilno savremenom načinu života. Upravo iz navedenog razloga važno je apostrofirati i preventivni aspekt koji inkorporira sve institucionalne i vaninstitucionalne oblike (re)akcije na zloupotrebu, odnosno konzumiranje alkohola kada je u pitanju ova specifična starosna kategorija - maloljetna lica.

S obzirom na međusobnu povezanost, uslovljenost i (sa)djelovanje zloupotrebe, odnosno konzumiranja alkohola maloljetnih lica sa prestupničkim ponašanjem, proizlazi realna potreba uključivanja u preventivni proces svih institucionalnih i vaninstitucionalnih subjekata ali i pojedinaca kao autoriteta na planu blagovremenog prepoznavanja i identifikacije svih rizičnih ponašanja kod maloljetnih lica koja se neposredno ili posredno mogu dovesti u vezu sa zloupotrebom, odnosno konzumiranjem alkohola.

Promatrano kroz prizmu prevencije, posebno zabrinjava činjenica da se konzumiranje alkohola od strane ove starosne kategorije smatra društveno prihvatljivim ili poželjnim odnosno da ne postoji potrebna i povećana svijest kod građana o štetnosti alkohola i njegovim izuzetno negativnim posljedičnim dejstvima na maloljetna lica u smislu njihovog pravilnog razvoja i uključivanja u društvene procese u okruženju. S tim u vezi, porodica odnosno članovi porodice, prije svega imaju ključnu preventivnu ulogu i značaj na planu blagovremenog prepoznavanja i identifikacije svih rizičnih ponašanja koja ukazuju na mogućnost konzumiranja alkohola od strane maloljetnog lica.

Takođe, nezanemariv doprinos na planu blagovremene preventivne (re)akcije imaju i svi drugi subjekti (škola i duge obrazovne ustanove, sportski kolektivi, religijske zajednice, mediji i dr) i pojedinci kao autoriteti (nastavno osoblje, socijalni radnici, pedagozi, psiholozi i dr.). 
Blagovremeno djelovanje u vezi sa prepoznavanjem određenih rizičnih ponašanja omogućava i blagovremeno otklanjanje ili reduciranje rizikofaktora koji neposredno ili posredno pogoduju zloupotrebi, odnosno konzumiranju alkohola kod maloljetnih lica. Pojačan instruktivno-kontrolni nadzor nad maloljetnim licima kao i pravilan pristup omogućavaju da maloljetno lice blagovremeno shvati značaj i bude svjesno potencijalnog ili realnog rizika i štetnosti tj. negativnog djelovanja konzumiranja alkohola na njegov pravilan razvoj.

Takođe, sa aspekta prevencije potrebno je naglasiti da uključivanje maloljetnih lica u određene društveno korisne projekte i njihovo pravilno korišćenje slobodnog vremena ima prvorazrednu ulogu i značaj u procesu prevencije.

S obzirom na prisutnost i dostupnost različitih opojnih droga, te prisutnu ovisnost maloljetnih lica sa tendencijom snižavanja starosne dobi korisnika odnosno konzumenata opojnih droga, zatim prisutnost raznih oblika kockanja (različite igre na sreću, kladionice i dr), prosjačenje kao i neke druge društveno neprihvatljive obrasce ili modele ponašanja, vrlo često se neopravdano zanemaruje i ignoriše problem zloupotrebe, odnoso konzumiranja alkohola od strane maloljetnih lica, tako da se ovom društveno negativnom fenomenu i njegovoj prevenciji kada su u pitanju maloljetna lica ne poklanja dužna pažnja od strane naučno-stručne ali i opšte, odnosno laičke javnosti.

\section{ALKOHOLIZAM I KAZNENOPRAVNA ZAŠTITA MALOLJETNIH LICA}

Prilikom komparativne analize kaznenopravnih odredbi zakona koje se odnose na alkoholizam, odnosno zloupotrebu alkohola maloljetnih lica, potrebno je naglasiti veoma kompleksnu ustavnopravnu strukturu države Bosne i Hercegovine koja određuje i determinira vršenje sudske, zakonodavne i izvršne vlasti na svim nivoima - državni nivo, entiteti: Federacija Bosne i Hercegovine (i u okviru iste kantonalni nivoi) i Republika Srpska, te Distrikt Brčko. U okviru ovako kompleksne ustavnopravne strukture Bosne i Hercegovine, kaznenopravna zaštita maloljetnih lica od zloupotrebe alkohola postiže se krivičnopravnim i prekršajnopravnim normama, odnosno odredbama iz Krivičnog zakona i Zakona o prekršajima protiv javnog reda i mira. U tom smislu, inkriminacije, odnosno odredbe koje se odnose na zloupotrebu i odavanje alkoholu maloljetnih lica propisane su u krivičnom i prekršajnom zakonodavstvu. Polazeći od takve propisanosti inkriminacija, odnosno odredbi povezanih sa zloupotrebom i odavanjem alkoholu maloljetnih lica, postoje dva osnovna kaznenopravna aspekta zaštite maloljetnih lica od zloupotrebe i odavanja alkoholu: krivičnopravna i prekršajnopravna zaštita maloljetnih lica.

\subsection{Krivičnopravna zaštita maloljetnih lica od alkoholizma}

Analizom odredbi krivičnih zakona na sva četiri nivoa, evidentno je da postoji razlika u pogledu krivičnih djela, odnosno krivičnopravnih odredbi koje su povezane sa zloupotrebom i odavanjem maloljetnih lica alkoholu. Te razlike se odnose, $s$ jedne strane, na nepropisanost inkriminacija povezanih sa zloupotrebom alkohola maloljet- 
nih lica u svim krivičnim zakonodavstvima u Bosni i Hercegovini, te, s druge strane, na različitu kaznenu politiku, odnosno različitu visinu kazne u pogledu krivičnopravnih odredbi koje se odnose na zloupotrebu i odavanje maloljetnih lica alkoholu.

$\mathrm{U}$ pogledu inkriminacija kojima se maloljetnim licima pruža krivično pravna zaštita od zloupotrebe i odavanja alkoholu, u KZ FBiH i KZ BD BiH propisane su dvije inkriminacije i to "služenje alkoholnih pića mlađim maloljetnicima"11 iz člana 237. KZ Federacije BiH i člana 231. KZ Brčko distrikta $\mathrm{BiH}$ i „zapostavljanje ili zlostavljanje djeteta ili maloljetnika" iz člana 219. KZ FBiH i čl. $216 \mathrm{KZ} \mathrm{BD} \mathrm{BiH,}$ kao i inkriminacija „zapuštanje i zlostavljanje djeteta“ iz člana 187. KZ RS. Radi se o inkriminacijama koje su u posebnom dijelu krivičnog zakona sistematizovane u različite grupe krivičnih djela, odnosno krivična djela protiv zdravlja i krivična djela protiv braka, porodice i mladih ${ }^{12}$ i kod kojih je svojstvo (uzrasna dob maloljetnika) pasivnog subjekta obilježje bića krivičnog djela.

Krivičnopravna zaštita maloljetnih lica od od zloupotrebe alkohola se kod ovih inkriminacija postiže na različit način tako što se kod prve inkriminacije maloljetna lica štite od neposrednog konzumiranja alkoholnog pića proizašlog iz inkriminirajuće radnje posluživanja alkoholnih pića mlađim maloljetnicima, dok se kod druge inkriminacije maloljetna lica štite od odavanja alkoholu kao posljedične radnje uzrokovane prethodno preduzetim radnjama zanemarivanja iz osnovnog oblika djela i opciono propisanih kvalifikatornih radnji zlostavljanja, odnosno prinuđavanja maloljetnog lica na štetne radnje iz težeg oblika djela.

S obzirom da je prodaja ili posluživanje maloljetnika alkoholnim pićem kao prekršaj protiv javnog reda i mira predviđen u prekršajnom zakonodavstvu oba entiteta u Bosni i Hercegovini i Brčko distriktu $\mathrm{BiH}$, može se reći da je u kaznenom (krivičnom i prekršajnom) zakonodavstvu Federacije BiH i Brčko distrikta $\mathrm{BiH}$ posluživanje maloljetnika alkoholnim pićem propisano, odnosno predviđeno i kao krivična i kao prekršajna inkriminacija, dok je u kaznenom zakonodavstvu Republike Srpske propisano samo kao prekršajna inkriminacija, uz propisanost kvalifikatorne odredbe kod krivičnog djela "Zapuštanje ili zlostavljanje djeteta" koja se odnosi na odavanje maloljetnika alkoholu kao posljedice ovog krivičnog djela.

\subsubsection{Služenje alkoholnih pića mlađim maloljetnicima}

Inkriminacija pod nazivom „služenje alkoholnih pića mlađim maloljetnicima“ propisana je u krivičnim zakonodavstvima Federacije $\mathrm{BiH}$ i Brčko distrikta $\mathrm{BiH}^{13}$ i sistematizovana u posebnom dijelu krivičnog zakona u grupu krivičnih djela protiv zdravlja ljudi.

11 Službene novine FBiH, br. 75/17 i Službeni glasnik Brčko distrikta BiH, br. 50/18.

12 Iako je inkriminacija „zapuštanje ili zlostavljanje djeteta ili maloljetnika“ sistematizovana u grupu krivičnih djela protiv braka, porodice i mladih, zdravlje kao objekat krivičnopravne zaštite se javlja i kod djela iz ove grupe, pa tako i kod ove inkriminacije, tako da se ovom inkriminacijom štiti i zdravlje i psihofizički razvoj maloljetnih lica, u okviru skladnih porodičnih odnosa, koje je svakako ugroženo usljed propisanih radnji zanemarivanja i opciono propisanih radnji zlostavljanja, odnosno prinuđavanja maloljetnih lica na određene nedozvoljene, odnosno štetne radnje za zdravlje i razvoj maloljetnih lica.

13 Ova inkriminacija iz krivičnih zakonodavstava entiteta FBiH i Brčko distrikta BiH je jedna od rijetko propisanih inkriminacija u krivičnim zakonodavstvima i ista nije propisana u krivičnom zakonodavstvu entiteta Republika Srpska, kao i u krivičnim zakonodavstvima susjednih zemalja. 
Cilj propisivanja ove inkriminacije u navedenim krivičnim zakonodavstvima je dvostruke prirode i zasniva se na zdravstvenim i kriminalnopolitičkim razlozima. Razlozi zdravstvene prirode propisivanja ove inkriminacije se ogledaju u zaštiti zdravlja i nesmetanog psihofizičkog razvoja mlađih maloljetnika, odnosno lica do navršenih šesnaest godina njihove starosti od štetnog uticaja ${ }^{14}$ koje na tu uzrasnu kategoriju lica može imati konzumiranje alkoholnih pića. Kriminalno politički razlozi ogledaju u sprečavanju zloupotrebe alkohola kao opojnog sredstva u odnosu na ovu kategoriju lica u smislu njegovog konzumiranja, te sprečavanju širenja zloupotrebe alkohola među najmlađim članovima društva i sticanja zavisnosti o istom, kao i sprečavanju činjenja inkriminirajućih radnji povezanih sa zloupotrebom alkohola, odnosno učinjenih pod uticajem alkohola ili usljed zavisnosti o alkoholu ${ }^{15} \mathrm{sa}$ posebnim akcentom na činjenje krivičnih djela nasilnog karaktera. ${ }^{16}$

Ovo krivično djelo čini onaj ko u ugostiteljskom ili drugom objektu u kojem se prodaju alkoholna pića posluži mlađeg maloljetnika žestokim alkoholnim pićem ili ga posluži ${ }^{17}$ drugim alkoholnim pićem ${ }^{18} \mathrm{u}$ količinama koje mogu izazvati pijanstvo, odnosno pijano stanje maloljetnika. Učinitelj ovog krivičnog djela može biti sva-

14 Štetan uticaj alkoholnog pića na zdravlje mlađih maloljetnika kod ove inkriminacije može, u pravilu i u češćim slučajevima, da proizađe iz akutne intoksikacije nastale nakon konzumiranja određene količine alkoholnog pića, usljed osjetljivosti maloljetnih lica, u individualnim slučajevima, na alkohol i njegovo djelovanje na njihov organizam, kao i u rjeđim i izuzetnim slučajevima iz zavisnosti od alkohola nastale usljed čestog konzumiranja alkoholnog pića.

Z. Rajić, M. Tomić, Z. Miljko /2000/: Komentar kaznenog zakona Federacije BiH, Mostar, p. 363.

16 Danas je veoma izražena incidenca velike prevalencije maloljetnika u činjenju krivičnih djela pod uticajem alkohola, tako da su česti slučajevi da maloljetnici pod uticajem alkohola čine brojna krivična djela, a pogotovo ona krivična djela koja u ranijem, a prevashodno prijeratnom, periodu nisu bila svojstvena ovoj kategoriji lica kao što su krivična djela ubistva, silovanja, učestvovanje u tuči, nanošenje teških tjelesnih povreda, razbojništvo itd.

17 Zakonodavac u formulaciji odredbe i u pogledu posluživanja (mlađih) maloljetnika žestokim alkoholnim pićem i u pogledu posluživanja drugim alkoholnim pićem koristi izraz „posluži“ što podrazumijeva jednokratnost inkriminirajuće radnje posluživanja tako da je dovoljno poduzimanje i samo jedne radnje posluživanja alkoholnog pića mladim maloljetnicima. U ranijem krivičnom zakonu entiteta $\mathrm{FBiH}$ koji je bio u primjeni od 1998 (SN FBiH br. 43/98) pa do stupanja na snagu, odnosno primjene novog zakona od 2003. godine (SN FBiH br. 36/03), kod ovog krivičnog djela (iz člana 251. tadašnjeg zakona) za posluživanje maloljetnika drugim alkoholnim pićem zakonodavac je koristio termin „poslužuje“ kao trajni glagol što je podrazumijevalo poduzimanje više akata posluživanja, odnosno većeg broja posluživanja maloljetnika drugim alkoholnim pićem. U novom krivičnom zakonodavstvu entiteta $\mathrm{FBiH}$, i u pogledu posluživanja maloljetnika drugim alkoholnim pićem, trajni glagolski izraz "poslužuje“ je zamijenjen izrazom „posluži“ jer je stanovište da se i drugo alkoholno piće u količinama koje mogu dovesti do opijanja, odnosno stanja pijanstva maloljetne osobe može poslužiti poduzimanjem samo jednog čina posluživanja (npr. posluživanje boce, odnosno flaše vina koje je naručio maloljetnik može uzrokovati stanje pijanstva jednim činom posluživanja), tako da se i stanje pijanstva maloljetne osobe drugim alkoholnim pićem, zbog posebne osjetljivosti organizma maloljetnih lica na alkoholna pića i u manjim procentima, može prouzrokovati, odnosno nastati samo jednim činom posluživanja. Ranija zakonska formulacija trajnog glagolskog izraza „poslužuje“ drugim alkoholnim pićem u ovoj inkriminaciji bi bila primjenjiva na punoljetna lica kod kojih, u pravilu, stanje pijanstva uzrokovanog konzumiranjem drugog alkoholnog pića, odnosno alkoholnog pića sa manjim procentom alkohola, ne bi proizašlo iz jedne već iz više radnji posluživanja.

18 U žestoka alkoholna pića se ubrajaju rakija, viski, votka, rum, džin i sl, a u druga alkoholna pića sa manjim procentom alkohola ubrajaju se pivo, vino itd. 
ka osoba, pri čemu je to, u pravilu, (punoljetna) osoba koja u ugostiteljskoj radnji ili drugom objektu u kojem se prodaju alkoholna pića poslužuje, odnosno prodaje alkoholna pića. U pravilu se kao učinitelj pojavljuje zaposlenik ugostiteljskog objekta, ali to može biti i neka druga osoba kao što je vlasnik tog objekta ili osoba koja samo faktički poslužuje goste ili prodaje alkoholno piće. ${ }^{19}$ Pasivni subjekt kod ove inkriminacije je osoba ispod 16 godina i radi se o inkriminaciji kod koje je svojstvo (uzrasna dob) pasivnog subjekta obilježje bića krivičnog djela.

Radnja izvršenja ovog krivičnog djela se sastoji u posluživanju mlađeg maloljetnika žestokim alkoholnim pićem ili drugim alkoholnim pićem u količinama koje mogu dovesti do opijanja tog maloljetnika, pri čemu se pod posluživanjem podrazumijeva prodaja i svako drugo davanje alkoholnog pića maloljetniku ${ }^{20} \mathrm{uz}$ postojanje svijesti da će maloljetnik to piće konzumirati. ${ }^{21} \mathrm{U}$ pogledu posluženja mlađeg maloljetnika alkoholnim pićem, ovo djelo podrazumijeva jednokratno posluženje maloljetnika alkoholnim pićem jer je takvo posluživanje dovoljno za postojanje djela. U slučaju višekratnog posluženja mladjeg maloljetnika alkoholnim pićem, uz ispunjenje zakonskih obilježja ovog krivičnog djela, može se, pod uslovima propisanim u članu 55. Krivičnog zakona $\mathrm{FBiH}$, raditi o produženom krivičnom djelu. ${ }^{22}$

Alkoholna pića kojima se poslužuju ovi maloljetnici moraju biti žestoka alkoholna pića ili druga alkoholna pića, ali u količinama koje mogu dovesti do opijanja maloljetnika. Kada su u pitanju žestoka alkoholna pića, količina kojom se poslužuju maloljetnici je irelevantna za postojanje krivičnog djela tako da je zakonodavac $\mathrm{u}$ formulaciji odredbe ove inkriminacije uopšte ne navodi. Međutim, kada su u pitanju druga alkoholna pića ona moraju biti poslužena maloljetnicima u količini koja može dovesti do opijanja maloljetnika, pri čemu je ta količina svakako manja ${ }^{23}$ od količine koja je potrebna za opijanje odraslih punoljetnih lica. ${ }^{24}$ Kada je u pitanju količina alkoholnih pića koja može dovesti do opijanja maloljetnika, određivanje te količine predstavlja quaestio facti u svakom konkretnom slučaju, a što zavisi od brojnih faktora medju kojima su odlučujući psihofizičko stanje zdravlja i uzrasta maloljetnika, količina konzumiranog alkoholnog pića, stepen alkohola u piću i sl. ${ }^{25}$

S obzirom na posljedicu, ova inkriminacija predstavlja delikt ugrožavanja sa apstraktnom opasnošću što znači da nije potrebno da se maloljetno lice opije, tako da je ovo djelo dovršeno samim posluživanjem maloljetnika alkoholnim pićem neovisno od toga da li je maloljetnik uopšte otpočeo sa konzumiranjem posluženog alkoholnog pića. U članu 240. KZ FBiH koji se odnosi na teška djela protiv zdravlja

19 M. Babić, Lj. Filipović, I. Marković, Z. Rajić /2005/: Komentari krivičnih/kaznenih zakona u Bosni i Hercegovini, Sarajevo, p. 1053.

20 S. Horović /2000/: Kazneno pravo - posebni dio, Mostar, p. 122.

21 Z. Tomić /2007/: Krivično pravo - posebni dio, Sarajevo, p. 162.

22 M. Babić et.al: op. cit., p. 1053.

23 Kada su u pitanju maloljetna lica količina alkoholnog pića koja može dovesti do stanja pijanstva je znatno manja u odnosu na količinu koja kod punoljetnih lica može uzrokovati takvo stanje. Takvo što je i razumljvo iz razloga što je organizam maloljetnih lica osjetljiviji na alkohol od punoljetnih lica, tako da je i štetno dejstvo alkohola izraženije kod maloljetnih lica. 
ljudi nije predviđen, odnosno propisan teži oblik djela služenja alkoholnih pića mlađim maloljetnicima kvalifikovan težom posljedicom. Ukoliko bi, međutim, usljed služenja alkoholnih pića (mlađim) maloljetnicima došlo do težih posljedica, odnosno do teškog narušenja zdravlja ili smrti maloljetnika radilo bi se o sticaju ovog krivičnog djela i nekih od krivičnih djela protiv života i tijela, odnosno o sticaju krivičnog djela služenje alkoholnih pića mlađim maloljetnicima i krivičnog djela prouzrokovanje smrti iz nehata iz člana 168 . KZ FBiH, odnosno krivičnog djela teška tjelesna povreda iz člana 172. st. 6 . KZ FBiH, pod uslovom da je počinilac postupao iz nehata u odnosu na smrt ili teško narušenje zdravlja maloljetne osobe.

Imajući u vidu da je ovo djelo dovršeno samim posluživanjem mlađeg maloljetnika, te da se to posluživanje, u pravilu, vrši u ugostiteljskoj ili drugoj radnji u kojoj se prodaje, odnosno poslužuje alkoholno piće, postojanje ovog krivičnog djela ovisi o mjestu posluživanja mlađeg maloljetnika alkoholnim pićem kao zakonskom obilježju ovog krivičnog djela. Mjesto obavljanja ove inkriminirajuće radnje posluživanja alkoholnim pićem mlađih maloljetnika, u pravilu, vezano je za objekte u kojima se obavlja ugostiteljska i trgovinska djelatnost, pri čemu za postojanje djela nije bitan karakter rada tih objekata u kojima se prodaju alkoholna pića, tako da će ovo djelo postojati i ako se posluživanje, odnosno prodaja alkoholnog pića mlađim maloljetnicima, pored objekata koji imaju trajniji karakter, obavlja i u objektima koji su privremenog ili provizornog karaktera (objekti za prodaju pića na sajmovima, izložbama, sportskim takmičenjima itd). Kod ovog krivičnog djela je bitno da se inkriminirajuća radnja posluživanja alkoholnih pića mlađim maloljetnicima vezuje za objekat i prostor oko objekta, odnosno obavlja u objektu ili prostoru koji pripada objektu, tako da nema ovog krivičnog djela ukoliko je posluživanje alkoholnim pićem mlađeg maloljetnika izvršeno izvan ugostiteljskog objekta ili druge (trgovinske) radnje u kojoj se poslužuje alkoholnim pićem, odnosno nema ovog krivičnog djela ukoliko je to posluživanje izvršeno npr., u privatnom stanu, na nekoj zabavi itd.

U pogledu oblika krivnje sa kojim učinilac postupa pri izvršenju djela, ovo krivično djelo može se izvršiti samo sa umišljajem, tako da je za postojanje krivičnog djela, odnosno krivnje učinioca djela potreban umišljaj koji obuhvata svijest učinioca djela o vrsti i količini posluženog alkoholnog pića, te svijest učinioca o starosnoj dobi ${ }^{26}$ lica koje poslužuje alkoholnih pićem i o namjeri maloljetnika da konzumira to piće. To. zapravo, znači da se umišljaj učinioca ovog djela ogleda u njegovoj svijesti da se alkoholna pića određene vrste i jačine, odnosno u određenoj količini, daju licu koje nije navršilo 16 godina i svijesti da će mlađi maloljetnik konzumirati to piće, odnosno da ga kupuje za sebe a ne za druge osobe. To znači da nema ovog krivičnog djela ukoliko se radi o posluživanju, odnosno prodaji alkoholnog pića mlađem maloljetniku koje on ne kupuje za sebe već za druge osobe starije od 16 godina. ${ }^{27}$ Utvrđivanje da li mlađi maloljetnik kupuje alkoholno piće za sebe ili drugog je kompleksno i predstavlja faktičko pitanje koje, u zavisnosti od okolnosti činjeničnog stanja, sud utvrđuje u svakom konkretnom slučaju.

26 U pogledu uzrasne dobi, odnosno starosti lica koje se poslužuje alkoholnim pićem dovoljan je i eventualni umišljaj kod učinioca djela, što znači da će počinitelj ovog djela krivično odgovarati i kad nije tačno znao, već je samo pretpostavljao mogućnost da je osoba koju poslužuje mlađa od 16 godina pa je ipak pristao na posluženje te osobe alkoholnim pićem. 
Ova krivična inkriminacija pokazuje da je, dakle, zabrana posluživanja alkoholnim pićem ograničena samo na mlađe maloljetnike. To znači da prema krivičnom zakonodavstvu $\mathrm{FBiH}$ nema zabrane posluživanja alkoholnim pićem starijih maloljetnika, tako da posluživanje alkoholnim pićem ove uzrasne kategorije maloljetnika nije krivično djelo. Ovakvo zakonsko rješenje o inkriminisanju u krivičnom zakonodavstvu Federacije $\mathrm{BiH}$ i Brčko distrikta $\mathrm{BiH}$ samo posluživanja alkoholnim pićem mlađih, a ne i starijih maloljetnika iz više razloga nije dobro rješenje, tako da bi krivičnopravna zaštita od zloupotrebe alkohola kod ove inkriminacije, u vidu propisivanja zabrane posluživanja akoholnim pićem, trebala obuhvatiti i starije maloljetnike, te da se u krivičnom zakonodavstvu $\mathrm{FBiH}$ propiše izmijenjena inkriminacija pod nazivom „služenje alkoholnim pićem maloljetnika“.

Ratio legis izmjene naziva ove inkriminacije i proširivanja krivičnopravne zaštite, u vidu propisivanja zabrane posluživanja alkoholnih pića, i na kategoriju starijih maloljetnika je višestruke prirode, pri čemu preovladavaju zdravstveni i kriminalnopolitički razlozi. Naime, s jedne strane, svi razlozi zdravstvene prirode koji opravdavaju zabranu posluživanja alkoholnih pića mlađim maloljetnicima i ogledaju se u štetnom uticaju alkohola na zdravlje ove kategorije maloljetnika mogu se uzeti u obzir i kada su u pitanju stariji maloljetnici jer se i kod ove kategorije maloljetnika, zbog postojeće osjetljivosti njihovog organizma na alkohol, reflektuje štetan uticaj alkohola na njihovo zdravlje i psihofizički razvoj u istoj mjeri u kojoj se to odražava na mlađe maloljetnike, tako da se štetno dejstvo alkohola jednako reflektuje na obe kategorije maloljetnika.

Pored toga, jedan od razloga zdravstvene prirode povezan i sa kriminalnopolitičkim razlozima je i taj što do širenja zloupotrebe alkohola, odnosno konzumiranja alkoholnog pića i odavanja maloljetnika alkoholu, kao i sticanja zavisnosti o alkoholu među najmlađim članovima društva dolazi upravo u ovoj dobi usljed čestog konzumiranja alkoholnih pića ove kategorije lica.

Posljedično tome, na navedene zdravstvene razloge o opravdanosti propisivanja ove inkriminacije i proširivanja krivičnopravne zaštite, u vidu propisivanja zabrane posluživanja alkoholnih pića, i na kategoriju starijih maloljetnika, naslanjaju se i kriminalnopolitički razlozi koji se ogledaju u tome što je kod starijih maloljetnika, usljed raširenosti konzumiranja alkoholnog pića u ovoj uzrasnoj dobi, najizraženiji maloljetnički recidivizam pri čemu je u najvećoj mjeri prisutna incidenca činjenja brojnih inkriminirajućih radnji pod uticajem alkohola, kao i usljed odavanja alkoholu i prerano stečene zavisnosti o istom, tako da danas imamo sve veći broj starijih maloljetnika koji konzumirajući alkohol i pod njegovim odlučujućim uticajem, ili usljed zavisnosti o istom, čine krivična, kao i prekršajna djela sa elementima nasilja.

Takođe, uz zdravstvene i kriminalnopolitičke razloge, ratio legis izmjene ove inkriminacije $\mathrm{u}$ krivičnom zakonodavstvu $\mathrm{FBiH}$ je i normativne prirode i ogleda se u potrebi harmonizacije krivičnih i prekršajnih odredbi koje se odnose na posluživanje alkoholnim pićem maloljetnika, odnosno lica od 14 do 18 godina, jer se u prekršajnom zakonodavstvu na nivou kantona u $\mathrm{FBiH}$, kao i u prekršajnom zakonodavstvu Republike Srpske, prema Zakonu o prekršajima protiv javnog reda i mira, kao prekršaj smatra posluživanje alkoholnim pićem maloljetnika, odnosno i mlađih i starijih maloletnika. ${ }^{28}$ 


\subsubsection{Zapuštanje ili zlostavljanje djeteta ili maloljetnika}

Pored krivičnog djela „služenje alkoholnih pića mlađim maloljetnicima“, krivičnopravna zaštita maloljetnih lica od alkoholizma, odnosno zloupotrebe i odavanja alkoholu se ostvaruje i u krivičnoj inkriminaciji, iz grupe krivičnih djela protiv braka i porodice, pod nazivom "Zapuštanje ili zlostavljanje djeteta ili maloljetnika“ iz člana 219. KZ FBiH i člana 216. KZ BDBiH, odnosno „Zapuštanje i zlostavljanje djeteta“ iz člana 187. KZ RS.

Cilj propisivanja ove inkriminacije se ogleda u intenciji zakonodavca da zaštiti maloljetna lica od neodgovornog i po njihov psihofizički razvoj štetnog ponašanja prevashodno roditelja kao primarnih izvršilaca ${ }^{29}$ ovog djela, usvojitelja, staratelja ili drugih lica ${ }^{30}$ koji imaju zakonsku obavezu staranja o maloljetnoj djeci.

Ovom inkriminacijom se maloljetnim licima pruža krivično pravna zaštita od ugrožavanja njihovog zdravlja, odnosno psihofizičkog razvoja, kao i od vaspitnih devijacija i defekata u procesu socijalizacije po osnovu njihovog zapuštanja uzrokovanog radnjama zanemarivanja dužnosti zbrinjavanja i vaspitanja, kao i po osnovu preduzimanja neke od opciono propisanih radnji zlostavljanja od strane roditelja ili drugih lica kao izvršilaca djela. Takođe, ovom inkriminacijom se maloljetnim licima pruža i krivičnopravna zaštita od nastupanja težih posljedica proizašlih iz navedenih radnji zanemarivanja ili zlostavljanja manifestovanih $u$ vidu teškog narušenja zdravlja ili nastupanja smrti, kao i u vidu odavanja alkoholu ili drugim oblicima asocijalnog ponašanja ili delinkvenciji.

Treba istaći da povreda prava i dužnosti roditelja o zbrinjavanju i vaspitanju djece, zasnovane na ustavu zemlje i zakonskim propisima iz porodičnog zakonodavstva, kao i na Konvenciji UN o pravima djeteta, ${ }^{31}$ uz preduzimanje radnji zlostavljanja, predstavlja jedan od glavnih faktora maloljetničke delinkvencije, tako da ova inkriminacija na neki način predstavlja oblik državno pravne reakcije koja ima za cilj da spriječi kriminalizaciju ličnosti maloljetnog lica. ${ }^{32}$ Kriminalizacija ličnosti maloljetnog lica, pored navedenih radnji zanemarivanja iz osnovnog i zlostavljanja iz drugog, težeg oblika ovog djela, može da proizidje i iz odavanja maloljetnog lica alkoholu, kao jednom od oblika asocijalnog ponašanja maloljetnih lica koje se ta-

na mlađe maloljetnike, tako da je u krivičnom i prekršajnom zakonodavstvu Brčko distrikta $\mathrm{BiH}$ potrebno harmonizovati ove odredbe proširivanjem zabrane posluživanja alkoholnim pićem i na starije maloljetnike.

29 Primarno staranje roditelja o zbrinjavanju i vaspitanju njihove djece, pored ustavne i zakonske obaveze, kao i obaveze i odgovornosti propisane Konvencijom UN o pravima djeteta, proizlazi iz njihove biološke datosti, odnosno iz njihove uloge kao bioloških roditelja.

30 Dužnost drugih lica na zbrinjavanje i vaspitanje djece ili maloljetnika može, kao i kod roditelja, takođe proizlaziti iz porodičnopravnih propisa, kao i iz nekih drugih pravnih odnosa kao npr. ugovora, radnog odnosa i sl. U svojstvu drugih lica kao izvršilaca ovog krivičnog djela mogu se pojaviti maćeha, očuh, vaspitačica u vrtiću i sl. Bitno je da se radi o licima kod kojih, u odnosu prema djetetu ili maloljetniku o kojem su dužni da se staraju, postoji trajniji odnos koji bi omogućavao staranje (vid. M. Babić et. al. /2005/: op. cit., p. 1615).

31 Prema članu 18. st.1. Konvencije UN o pravima djeteta roditelji ili zakonski skrbnici imaju najveću odgovornost na zbrinjavanju i vaspitanju djeteta, tako da dobrobit djeteta mora biti njihova temeljna briga.

M. Babić et. al. /2005/: op. cit., p. 1613. 
kođe javlja kao posljedica radnji zanemarivanja i zlostavljanja kao oblika ovog djela, jer je odavanje alkoholu, uz konzumiranje opojnih droga, jedan od prevalirajućih faktora maloljetničke delinkvencije, tako da imamo prevalirajuću incidencu činjenja brojnih inkriminirajućih radnji maloljetnih lica pod uticajem alkohola.

Inkriminacija „zapuštanje ili zlostavljanje djeteta ili maloljetnika“ iz člana 219 KZ FBiH ima tri oblika: zapuštanje djeteta ili maloljetnika kao osnovni oblik djela propisan u stavu 1 i zlostavljanje djeteta ili maloljetnika, kao drugi, teži oblik, propisan u stavu 2. ovog člana, te kvalifikatorni oblik djela propisan u stavu 3 koji se odnosi na nastupanje teških posljedica po dijete ili maloljetnika usljed radnji iz dva oblika djela. Zapuštanje i zapostavljanje kao dva oblika, odnosno kao osnovni i teži oblik, ovog djela imaju svoje razlike i sličnosti tako da se razlikuju u pogledu radnje izvršenja i u pogledu posljedice ${ }^{33}$ djela, dok su im zajednička obilježja lično svojstvo izvršioca i pasivni subjekt djela. Kod ove inkriminacije sadržinski se radi o dva krivična djela koja su propisana kao dva oblika ovog krivičnog djela.

\subsubsection{Zapuštanje djeteta ili maloljetnika}

Zapuštanje djeteta ili maloljetnika, kao osnovni oblik djela, uzrokovano je radnjama grubog zanemarivanja zbrinjavanja i vaspitanja ${ }^{34}$ od strane roditelja ili drugih lica koji su dužni da se o njemu staraju. Zapuštenost može biti uzrokovana sa dva oblika zanemarivanja: običnim i grubim zanemarivanjem. Sa krivičnopravnog aspekta zapuštenost mora biti rezultat ne običnog, već grubog, odnosno većeg stepena, zanemarivanja svoje dužnosti zbrinjavanja i vaspitanja, što upućuje na trajnije i ozbiljnije zanemarivanje elementarnih dužnosti u zbrinjavanju i vaspitanju djeteta ili maloljetnika. ${ }^{35}$ To znači da je u krivično pravnom smislu irelevantna uzrokovanost zapuštenosti djeteta ili maloljetnika radnjom običnog zanemarivanja ${ }^{36}$ jer zanemarivanje roditeljskih prava i dužnosti o zbrinjavanju i vaspitanju djeteta koje nema ele-

33 Posljedica kod zapuštanja se ogleda u prouzrokovanju stanja zapuštenosti djeteta ili maloljetnika koje može biti psihičko i fizičko pri čemu između radnje grubog zanemarivanja i zapuštenosti, kao i kod drugih posljedičnih krivičnih djela mora da postoji uzročni odnos (vid. Z. Stojanović /2019/: Komentar Krivičnog zakonika, deveto izmenjeno i dopunjeno izdanje, Službeni glasnik, Beograd, p. 639), dok se kod zlostavljanja posljedica ogleda u ugrožavanju i povredi fizičkog i psihičkog integriteta djeteta ili maloljetnika.

34 Grubo zanemarivanje dužnosti odgoja djeteta izražava se u nepreduzimanju aktivnosti koje su neophodne za odgoj djeteta ili za sprečavanje njegove negativne socijalizacije. Takav vid grubog zanemarivanja djeteta postojao bi u sljedećim situacijama: kada roditelj svojim načinom života daje loš primjer djetetu (bavi se kriminalom), kad odobrava asocijalno ponašanje djeteta (npr. prosjačenje, bježanje iz škole i sl), nagovara ili pomaže djetetu da pobjegne iz odgojne ustanove itd. Grubo zanemarivanje dužnosti zbrinjavanja djeteta podrazumjeva propuštanje da se obezbjede osnovni uslovi egzistencije maloljetnog lica (ishrana, stanovanje, odjevanje, liječenje i sl). Takav vid grubog zanemarivanja djeteta postojao bi u sljedećim situacijama: kada roditelj odbija da radi, kad sav svoj prihod troši na neke druge aktivnosti (izlasci, kockanje i sl), kad prodaje stvari koje su neophodne za egzistenciju maloljetnog lica itd (vid. M. Babić, I. Marković /2018/: Krivično pravo - posebni dio, Pravni fakultet, Banja Luka, p. 151).

35 Z. Tomić /2003/: op.cit., p. 129.

36 Insistiranjem na grubom zanemarivanju dužnosti zbrinjavanja i vaspitanja djeteta, intencija zakonodavca je bila da odvoji zanemarivanje djeteta sa elementima grubosti, što je krivično djelo, od drugih oblika zanemarivanja, odnosno običnog ili zanemarivanja bez elemenata grubosti koje nema obilježja krivičnog djela, te ne podliježe pod udar krivičnih sankcija i zaslužuje neki blaži 
mente grubosti ${ }^{37}$ ne može biti razlog za krivičnopravnu reakciju i inkriminisanost $\mathrm{u}$ krivičnom zakonodavstvu, već razlog za preduzimanje određenih mjera organa starateljstva (preventivni nadzor) ili za lišavanje roditeljskih prava. ${ }^{38}$ To, zapravo, znači da unošenje pojma "grubosti“ medju objektivna obilježja bića krivičnog djela zapuštanje uzrokovanog zanemarivanjem zbrinjavanja i vaspitanja djeteta ili maloljetnika je neophodno iz razloga sprečavanja krivično pravne intervencije u porodično vaspitanje djeteta, tako da određene devijacije u odnosu roditelja prema djetetu koje imaju elemente običnog zanemarivanja nisu predmet krivičnopravne intervencije već su predmet intervencije organa socijalne zaštite i drugih nadležnih organa.

Elemenat grubog zanemarivanja kao uzrok nastupanja zapuštenosti djeteta, kao jednog od oblika krivičnog djela, može biti prisutan ne samo kod jednog već i kod oba roditelja s tim da je u takvim slučajevima dejstvo štetnih posljedica po dijete mnogo veće, tako da je zapuštenost djeteta mnogo izraženija i po obimu i po intenzitetu.

Pasivni subjekt kod ovog oblika djela je dijete, odnosno lice do 18 godina u odnosu na koje postoji dužnost zbrinjavanja i vaspitanja od strane roditelja ili drugih lica koja su dužna da se o njemu staraju. U pogledu krivnje u odnosu na zapuštanje djeteta kao osnovni oblik djela potreban je umišljaj koji treba da obuhvati svijest učinioca da se ne radi o običnom zanemarivanju već da je u pitanju grubo zanemarivanje dužnosti zbrinjavanja i vaspitanja.

U krivičnopravnoj teoriji se ne razmatra, odnosno ne ulazi u pitanje kumulacije ili alternacije područja brige o djetetu na koje je usmjerena radnja grubog zanemarivanja kao uzrok zapuštenosti djeteta. Naime, radnja grubog zanemarivanja, kao "condicio sine qua non" za postojanje ovog oblika djela je usmjerena na dva područja brige o djetetu, odnosno na područje zbrinjavanja i vaspitanja. Premda su u najvećem broju slučajeva ova dva područja brige o djetetu medjusobno usko povezana i uslovljena tako da je, u pravilu, grubo zanemarivanje vaspitanja praćeno i odgovarajućom zanemarivanjem odnosno nebrigom o zbrinjavanju ili obrnuto, moguće su i situacije da bude zastupljen samo jedan oblik grubog zanemarivanja, odnosno nebrige o djetetu. $S$ tim u vezi, u cilju pojačane krivičnopravne zaštite maloljetnih lica od zapuštanja, za postojanje ovog oblika djela dovoljno je da grubo zanemarivanje bude izraženo i u jednom, a ne a priori u oba područja brige o djetetu jer insistiranje na ispoljavanju grubog zanemarivanja brige o djetetu i na području zbrinjavanja i području vaspitanja za postojanje zapuštenosti kao osnovnog oblika

sud o nevrednosti (npr. moralnu osudu) i odgovarajuću intervenciju organa socijalne zaštite (vid. B. Cvjetko, M. Singer /2013/: Kaznenopravna zaštita djece, Globus, Zagreb, p. 301).

37 Da bi postojalo ovo krivično djelo, neophodno je da se radi o grubom zanemarivanju dužnosti, odnosno o „svjesnom ispoljavanju krajnje brige i nemara za život i zdravlje djeteta i njegov odgoj“ (vid. Lj. Jovanović /1983/: Krivično pravo - posebni deo, Beograd, p. 300). Grubost kao obilježje bića ovog krivičnog djela po svojoj prirodi predstavlja normativni element koji pretpostavlja odgovarajući vrijednosni sud koji zavisi od okolnosti konkretnog slučaja. Zanemarivanje može biti objektivno ocijenjeno kao grubost s obzirom na intenzitet, učestalost i okolnosti pod kojima se realizuje, ali i s obzirom na subjektivne momente poput mržnje ili niskih nemoralnih motiva (vid. Z. Stojanović, N. Delić /2019/: Krivično pravo - posebni deo, Pravna knjiga, Beograd, p. 101).

N. Mrvić-Petrović /2019/: Krivično pravo - posebni deo, Pravni fakultet - Union, Beograd, p. 152. 
djela dovodi do limitiranosti krivičnopravne intervencije u zaštiti djeteta od zapuštanja što bi znatno suzilo i otežalo krivičnopravnu zaštitu djeteta, te time dovelo u otežan položaj dijete kao pasivnog subjekta ovog krivičnog djela.

\subsubsection{Zlostavljanje djeteta ili maloljetnika}

Zlostavljanje kao drugi i teži oblik ovog djela se sastoji u alternativno određenim radnjama zlostavljanja ili prinuđavanja djeteta ili maloljetnika na rad koji ne odgovora njegovom uzrastu ili na pretjerani rad ili na prosjačenje ili navođenja iz koristoljublja djeteta ili maloljetnika na ponašanje štetno za njegov razvoj. Kod ove inkriminacije se, zapravo, radi o opciono propisanim radnjama zlostavljanja, tako da se pored opšteg pojma zlostavljanja, odnosno zlostavljanja u opštem smislu u ovom obliku djela navodi još nekoliko modaliteta radnje koji su samo eklatantni primjeri zlostavljanja ili eksploatacije djeteta ili maloljetnika. ${ }^{39}$

Zlostavljanje ${ }^{40}$ znači izazivanje fizičke i psihičke boli jačeg intenziteta koje još ne predstavlja tjelesne povrede ili narušenje zdravlja. Sa krivičnopravnog aspekta mora se raditi o takvom zlostavljanju koje sadrži elemente očigledno grubog postupanja s djetetom ili maloljetnikom koje izlazi izvan okvira pedagoških standarda postupanja prema djetetu, tako da prelazi granice dopuštenog disciplinskog kažnjavanja djeteta ili razboritog postupanja $\mathrm{u}$ vaspitanju djeteta ili maloljetnika. $\mathrm{U}$ tom smislu, radnje zlostavljanja, u bilo kojem modalitetu, ni po svom cilju (vaspitanje) ni objektivno ne predstavljaju disciplinske mjere, već se radi o svojevrsnoj zloupotrebi roditeljskog prava koja se manifestuje u nametanju nepotrebnih i nepravedenih zahtjeva prema djetetu uz nanošenje fizičkih i psihičkih patnji. ${ }^{41}$

$\mathrm{S}$ obzirom na posljedicu proizašlu iz radnji zlostavljanja koja se manifestuje $\mathrm{u}$ ugrožavanju fizičkog i psihičkog integriteta djeteta ili maloljetnika, zlostavljanje se najčešče javlja kao fizičko u vidu nanošenja fizičkih bolova i neugoda (udaranje, izgladnjivanje), te kao psihičko koje često po dijete ostavlja teže posljedice od fizičkog (nesanice, govorne mane i sl). Psihičko zlostavljanje djeteta ili maloljetnika mogu prouzrokovati razni vidovi strašenja djeteta, vrijeđanje i ponižavanje djeteta koje ne predstavlja obične uvrede i pogrde počinjene u afektu već imaju karakter intenzivne netrpeljivosti prema djetetu i predstavljaju izraz bezdušnog, nečovječnog odnosa prema djetetu ili maloljetniku. ${ }^{42}$

U pogledu oblika krivnje učinioca, i kod ovog oblika djela učinilac postupa isključivo s umišljajem koji mora da obuhvati svijest o tome da se preduzima radnja zlostavljanja, kao i svijest da se ta radnja preduzima prema djetetu kao pasivnom subjektu ovog oblika djela.

39 S. Horović /2010/: Kazneno pravo - posebni dio, Mostar, p. 106.

40 Prema definiciji Svjetske zdravstvene organizacije, zloupotreba ili zlostavljanje djeteta obuhvataju sve oblike fizičkog, odnosno emocionalnog zlostavljanja, seksualnu zloupotrebu, zanemarivanje ili nemaran postupak, kao i komercijalnu i drugu eksploataciju, što dovodi do stvarnog ili potencijalnog narušavanja zdravlja djeteta, njegovog preživljavanja, razvoja ili dostojanstva u okviru odnosa koji uključuje odgovornost, povjerenje ili moć (vid. B. Išpanović-Radojković, T. Ignjatović /2011/: Zaštita dece od zlostavljanja i zanemarivanja, Centar za prava deteta, Beograd, p. 11).

41 M. Babić, I. Marković /2018/: op. cit., p.152.

42 Z. Rajić, M. Tomić, Z. Miljko: op. cit., p. 325. 
U slučaju da su roditelji, kao primarni izvršioci ovog djela, svojim ponašanjem i postupanjem prema djetetu, kroz preduzimanje nekih od opciono propisanih radnji zlostavljanja, ostvarili obilježja bića krivičnog djela zlostavljanje prema dvoje ili više svoje djece, u takvom slučaju postoji više krivičnih djela počinjenih u sticaju kojom prilikom se kazna utvrđuje za svako krivično djelo i izriče kao jedinstvena kazna.

\subsubsection{Teške posljedice zapuštanja ili zlostavljanja djeteta ili maloljetnika}

Kod krivičnog djela „Zapuštanje ili zlostavljanje djeteta ili maloljetnika“ u članu 219. st. 3. KZ FBiH propisan je kvalifikovani oblik koji sadrži više kvalifikatornih okolnosti koje se odnose na nastupanje, usljed radnji grubog zanemarivanja i zlostavljanja, teških posljedica koje se manifestuju u prouzrokovanju, odnosno nastupanju teške tjelesne povrede, teškom narušenju zdravlja ili u odavanju alkoholu, ${ }^{43}$ prostituciji ili drugim oblicima asocijalnog ponašanja ili delinkvenciji.

Propisivanje ovog, kvalifikovanog, oblika krivičnog djela rezultat je intencije zakonodavca da obezbijedi pojačanu krivičnopravnu zaštitu maloljetnih lica od ugrožavanja njihovog zdravlja i tjelesnog i psihičkog integriteta, te od društveno neprihvatljivih oblika ponašanja u koje ubrajamo i odavanje alkoholu, kao i od činjenja krivičnih djela uzrokovanih asocijalnim oblicima ponašanja maloljetnih lica.

Kod ovog oblika djela, za koje je propisana stroža kazna u odnosu na prva dva oblika djela, navedene kvalifikatorne okolnosti su alternativno postavljene tako da je za postojanje ovog teškog oblika, odnosno za primjenu ove kvalifikacije djela dovoljno da se ostvari jedna od njih. Ukoliko se ostvari više kvalifikatornih okolnosti uzrokovanih preduzetim radnjma zapuštanja, odnosno zanemarivanja ili zlostavljanja, to će biti od uticaja na odmjeravanje kazne.

Kada su u pitanju teške tjelesne povrede i trajno narušenje zdravlja maloljetnog lica, usljed radnji zanemarivanja ili zlostavljanja, kao kvalifikatorne okolnosti ovog oblika djela, treba istaći da pojam teških tjelesnih povreda i teškog narušenja zdravlja kod ove inkriminacije treba tumačiti u skladu sa tumačenjem krivičnog djela teške tjelesne povrede. ${ }^{44} \mathrm{U}$ pogledu oblika krivnje kod učinioca ovog djela u odnosu na navedene kvalifikatorne okolnosti, odnosno teške posljedice djela koje se ogledaju u nastupanju teške tjelesne povrede ili teškom narušenju zdravlja mora postojati nehat na strani učinioca. Ukoliko je, međutim, teška tjelesna povreda ili teško narušenje zdravlja maloljetnog lica bila obuhvaćena umišljajem (bilo direktnim ili indirektnim) učinioca djela, radiće se o namerno počinjenom krivičnom djelu teške tjelesne povrede iz člana 172. st. $1 . \mathrm{KZ} \mathrm{FBiH}^{45} \mathrm{u}$ idealnom sticaju s kvalifikovanim

43 U okviru kvalifikatorne odredbe koja se odnosi na teži oblik krivičnog djela „zapuštanje ili zlostavljanje djeteta ili maloljetnika" odavanje maloljetnika alkoholu kao posljedica ovog krivičnog djela je u nekim zakonodavstvima direktno propisano (vid. čl. 187. st. 3. KZ RS), a u nekim je propisano u okviru drugih oblika asocijalnog ponašanja (vid. čl. 219. st. 3. KZ FBiH i čl. 216. st. 3. KZ BD BiH).

44 M. Babić et.al.: op.cit., p. 1616.

45 Čl. 132. st. 1. KZ entiteta RS. U pogledu ovog djela propisana je različita visina zatvorske kazne između entitetskih krivičnih zakonodavstava. Naime, propisan je različit posebni minimum uz propisani isti posebni maksimum kazne, pa je time i različit raspon posebnog minimuma i mak- 
oblikom krivičnog djela zapuštanje ili zlostavljanje djeteta ili maloljetnika iz člana 219. st. 3. KZ FBiH.

Pored teške tjelesne povrede i teškog narušenja zdravlja djeteta ili maloljetnika kao kvalifikatornih okolnosti ovog djela, jedna od težih posljedica, odnosno alternativno propisanih kvalifikatornih okolnosti odnosi se na odavanje djeteta ili maloljetnika alkoholu i drugim oblicima asocijalnog ponašanja. ${ }^{46}$ Odavanje djeteta ili maloljetnika alkoholu i drugim asocijalnim i delinkventnim oblicima ponašanja javlja se, dakle, kao posljedica počinjenog djela u osnovnom i težem obliku, odnosno kao posljedica grubog zanemarivanja dužnosti vaspitanja i zbrinjavanja djeteta ili maloljetnika ili njegovog izlaganja nekim od opciono propisanih kvalifikatornih radnji zlostavljanja od strane roditelja, usvojitelja ili staratelja koje se odnose na zlostavljanje djeteta ili maloljetnika, njegovo prinuđavanje na pretjerani rad ili rad koji ne odgovara njegovom uzrastu, ili na prosjačenje ili na njegovo navođenje ${ }^{47} \mathrm{iz}$ koristoljublja na vršenje drugih štetnih radnji za njegov razvoj. ${ }^{48}$ Time je zakonodavac kod ovog krivičnog djela propisivanjem radnji koje su alternativno postavljene, odnosno određene kvalifikatorne okolnosti koja se odnosi na odavanje djeteta ili maloljetnika alkoholu, kao i drugim oblicima asocijalnog ponašanja djetetu ili maloljetniku osigurao (prema KZ RS), odnosno pružio dodatnu (prema KZ FBiH i KZ $\mathrm{BD} \mathrm{BiH}$ ) krivičnopravnu zaštitu od alkoholizma, odnosno zloupotrebe alkohola. ${ }^{49}$

simuma kazne unutar opšteg zatvorskog okvira, tako da je u KZ entiteta FBiH za ovaj oblik djela propisana kazna zatvora od šest mjeseci do pet godina, dok je u KZ entiteta RS propisana kazna zatvora od jedne do pet godina.

46 U literaturi postoje različiti pristupi u interpretaciji šta se podrazumjeva pod „drugim oblicima asocijalnog ponašanja“ Pojedini autori (vid. M. Babić, I. Marković /2018/: op. cit., p. 152) daju šire, ekstenzivnije, objašnjenje pa pod pojmom drugih oblika asocijalnog ponašanja, uz sociopatološke oblike ponašanja koji se odnose na alkoholizam, narkomaniju, prostituciju, kockanje, skitnju i prosjačenje, podrazumijevaju i druge oblike asocijalnog ponašanja kao što su: stalno bježanje iz škole, izbjegavanje rada, kao i svako drugo ponašanje koje predstavlja značajnije odstupanje od usvojenih normi ponašanja u datom društvu. Ima i autora (vid. Z. Tomić /2007/: op. cit., p. 136) koji daju restriktivnije, uže objašnjenje, smatrajući, odnosno vezujući asocijalno ponašanje isključivo za najčešče sociopatološke pojave kao što su prostitucija, alkoholizam, skitnja i prosjačenje, kockanje, uživanje opojnih droga, odnosno narkomanija itd.

47 Radnja navođenja maloljetnog lica na vršenje nekih drugih radnji štetnih po njegov razvoj odgovara podstrekavanju koje može da bude učinjeno na različite načine - verbalno, konkludentnom radnjom, prividnim odvraćanjem i sl. Radnju navođenja maloljetnog lica na vršenje nekih drugih radnji štetnih za njegov razvoj izvšilac mora preduzeti motivisan koristoljubljem, odnosno namjerom pribavljanja imovinske koristi, tako da je ovo subjektivno obilježje konstitutivno za postojanje krivičnog djela (vid. N. Mrvić - Petrović /2019/: op. cit., p. 155).

48 U druge radnje koje su štetne za razvoj djeteta, odnosno maloljetnika smatraju se npr: gatanje, sviranje na ulici, ples u kafani, traženje novca od drugih ljudi, iznošenje ili prodaja stvari iz kuće i sl. Ovakve radnje iz čl. 219. st. 2. KZ FBiH štetne za razvoj djeteta ili maloljetnika bi se ujedno mogle i smatrati, odnosno tretirati kao drugi oblici asocijalnog, odnosno sociopatološkog ponašanja u širem smislu.

49 U KZ entiteta RS jedini vid krivičnopravne zaštite mladih lica od alkoholizma, odnosno zloupotrebe alkohola i odavanja maloljetnih lica alkoholu se osigurava, odnosno ostvaruje kroz propisivanje kvalifikatorne okolnosti kod krivičnog djela „Zapuštanje ili zlostavljanje djeteta“ iz člana 187. st. 3. KZ RS (Službeni glasnik RS, br. 64/17 i 104/18) koja se odnosi na odavanje djeteta alkoholu i drugim oblicima asocijalnog ponašanja, kao posljedici grubog zanemarivanja vaspitanja djeteta (čl. 187. st. 1. KZ RS) ili njegovog izlaganja opciono propisanim kvalifikatornim radnjama (čl. 187. st. 2. KZ RS), dok se u KZ entiteta FBiH i KZ BD BiH krivičnopravna zaštita 
Da bi se ova kvalifikatorna okolnost, kao i kvalifikatorne okolnosti, odnosno teške posljedice djela koje se odnose na teške tjelesne povrede ili teško narušenje zdravlja djeteta ili maloljetnika mogle pripisati zapuštanju, odnosno radnjama zanemarivanja ili zlostavljanja djeteta potrebno je utvrditi kauzalnu vezu između ovih radnji iz osnovnog i težeg oblika djela i jedne od nastupjelih kvalifikatornih okolnosti. U pravilu, odavanje maloljetnog lica alkoholu ili drugom asocijalnom ili delinkventnom načinu ponašanja rezultat je složenog uticaja i interakcije mnogobrojnih faktora različite prirode ${ }^{50}$ tako da zanemarivanje nije i ne mora biti jedini $i$ isključivi razlog odavanja maloljetnog lica alkoholu ili drugom asocijalnom ponašanju ili delinkvenciji. S tim u vezi, da bi se odavanje maloljetnog lica alkoholu ili drugom asocijalnom obliku ponašanja ili činjenju krivičnih djela, u smislu postojanja kauzalne veze, moglo pripisati radnjama zanemarivanja, odnosno zlostavljanja dovoljno je da su te radnje u značajnoj mjeri sauzrokovale ovaj ili drugi asocijalni ili delinkventni obrazac ponašanja maloljetnog lica, tako da te radnje po stepenu doprinosa nastupanju, odnosno stepenu uzrokovanja nastupanja neke od tih kvalifikatornih okolnosti kod maloljetnog lica preovladavaju u odnosu na druge faktore, odnosno uzročnike.

S obzirom na to da se za postojanje ovog, kvalifikovanog, oblika djela traži da se dijete ili maloljetnik odalo ${ }^{51}$ alkoholu ili drugim oblicima asocijalnog ponašanja (kao posljedici preduzetih radnji iz osnovnog i težeg oblika ovog djela, iz člana 219. st 1. i 2. KZ FBiH), odnosno da je ono jedan od uslova za postojanje kvalifikovanog oblika ovog krivičnog djela (čl. 219. st. 3. KZ FBiH), neophodno je da kod djeteta, odnosno maloljetnika postoji opredjeljenje za takav način ponašanja ${ }^{52}$ koji se ogleda u konzumiranju alkoholnog pića, odnosno da takav način ponašanja prihvati

maloljetnih lica od alkoholizma, odnosno odavanja alkoholu ostvaruje kroz propisivanje inkriminacije: "služenje alkoholnih pića mlađim maloljetnicima“ iz člana 237. KZ FBiH (SN FBiH, br. 75/17) i člana 231. KZ BD BiH (SG BD BiH, br. 50/18), kao i kroz navedenu kvalifikatornu okolnost, tako da se propisivanjem kvalifikatorne okolnosti kod inkriminacije "Zapuštanje ili zlostavljanje djeteta ili maloljetnika" iz člana 219. st. 3. KZ FBiH i čl. 216. st.3. KZ BD BiH, uz propisivanje, ipak, nižeg posebnog minimuma i maksimuma kazne zatvora u odnosu na viši minimum i maksimum kazne zatvora propisan prema članu 187. st. 3. KZ RS, maloljetnim licima, uz navedenu inkriminaciju, pruža dodatna krivičnopravna zaštita. To znači da se maloljetnim licima u krivičnom zakonodavstvu entiteta $\mathrm{FBiH}$ i $\mathrm{BD} \mathrm{BiH}$ pruža sveobuhvatnija krivično-pravna zaštita od alkoholizma,odnosno zloupotrebe alkohola, uz jaču krivičnopravnu zaštitu maloljetnih lica od odavanja alkoholu u KZ entiteta RS u pogledu višeg iznosa propisane kazne za teži oblik krivičnog djela „Zapuštanje ili zlostavljanje djeteta" u odnosu na krivična zakonodavstva u entitetu $\mathrm{FBiH}$ i Brčko distriktu BiH.

50 B. Cvjetko, M. Singer /2013/: op. cit., p. 315.

51 „Odati se“ znači neko opredjeljenje za određeno ponašanje, usvojiti nešto kao svoje i to činiti (S. Horović /2010/: op. cit., p. 106).

52 Zakon traži da se dijete (ili maloljetnik) odalo alkoholu ili drugim oblicima društveno neprihvatljivog ponašanja, kao posljedici grubog zanemarivanja vaspitanja i zbrinjavanja djeteta (ili maloljetnika) ili prisiljavanja na brojne opciono propisane kvalifikatorne radnje štetne za razvoj djeteta ili maloljetnika, tako da za postojanje kvalifikatorne okolnosti, odnosno nastupanje posljedice koja se ogleda u odavanju djeteta, odnosno maloljetnika alkoholu ili drugim oblicima asocijalnog ponašanja nije dovoljno jednokratno delinkventno ili drugo društveno neprihvatljivo ponašanje djeteta,odnosno maloljetnika već zaista mora da se radi o ponašanju koje po raznim aspektima (pojavni oblik, modalitet i intenzitet) upućuje na usvojeni model ponašanja djeteta, odnosno maloljetnika. 
kao svoj i da ga stalno čini. ${ }^{53}$ Zakonska formulacija ove kvalifikatorne odredbe $\mathrm{u}$ kojoj se traži da se maloljetno lice, usljed zapuštanja ili zlostavljanja, odalo alkoholu i drugim oblicima asocijalnog ponašanja, nedvosmisleno ukazuje da za postojanje neke od tih kvalifikatornih okolnosti, odnosno za odavanje maloljetnog lica alkoholu nije dovoljno jednokratno društveno neprihvatljivo ponašanje (jednokratno konzumiranje alkoholnog pića), već da se radi o ponašanju (konzumiranju alkoholnog pića) koje po pojavnom obliku, modalitetima i intenzitetu upućuje na zaključak da je to manje ili više usvojeni model ponašanja. ${ }^{54}$

U pogledu oblika krivnje učinioca kod ove kvalifikatorne okolnosti, u odnosu na druge kvalifikatorne okolnosti, odnosno teške posljedice djela potreban je diferencirani pristup. ${ }^{55}$ Naime, za razliku od kvalifikatornih okolnosti koje se odnose na teške tjelesne povrede i teško narušenje zdravlja za koje se, kako je navedeno, traži nehat na strani učinioca, krivnja učinioca u pogledu kvalifikatornih okolnosti koje se odnose na odavanje alkoholu i drugim oblicima asocijalnog ponašanja ili delinkvenciji proteže se na oba oblika, odnosno može biti obuhvaćena i umišljajem i nehatom učinioca, tako da se ove kvalifikatorne okolnosti mogu, na temelju utvrđenih činjenica, pripisati bilo umišljaju, bilo nehatu učinioca. ${ }^{56}$

Ako je učinilac s umišljajem postupao da kod maloljetnika uzrokuje odavanje alkoholu (npr. radnjom navođenja, odnosno upornog nagovaranja na to) ili drugom asocijalnom ponašanju ili delinkvenciji, takodje će se raditi o kvalifikovanom obliku krivičnog djela zanemarivanja ili zlostavljanja djeteta ili maloljetnika, s tim da će u tom slučaju postupanje učinioca s umišljajem, u odnosu na prouzrokovanje posljedice, kao težim oblikom krivnje, uticati na odmjeravanje kazne.

Odavanje maloljetnika alkoholu ili drugom asocijalnom ponašanju (npr. odavanje konzumiranju opojnih droga) uzrokovano radnjama zanemarivanja ili zlostavljanja može dovesti i do autodestruktivnih posljedica kod djeteta ili maloljetnika u smislu samopovređivanja, samoranjavanja ili izvršenja samoubistva. S tim u vezi, ukoliko odavanje maloljetnika alkoholu, koje se javlja kao posljedica radnji znemarivanja ili zlostavljanja, uzrokuje kod djeteta ili maloljetnika izvršenje samoubistva, u tom slučaju radit će se o sticaju krivičnog djela učestvovanje u samoubistvu iz člana 170. st. 2 i 3 . $\mathrm{KZ} \mathrm{FBiH}^{57}$ sa kvalifikovanim oblikom krivičnog djela zapuštanje

M. Babić, I. Marković /2018/: op.cit., p. 153.

B. Cvjetko, M. Singer /2013/: op.cit., p. 315.

Z. Tomić /2007/: op.cit., p. 137.

To podrazumijeva da počinitelj, odnosno roditelj, usvojitelj, staratelj ili drugo lice može radnju grubog zanemarivanja vaspitanja ili zbrinjavanja djeteta ili maloljetnika iz osnovnog oblika iz člana 219. st. 1. KZ FBiH, ili opciono propisanih kvalifikatornih radnji iz težeg oblika iz stava 2 istog člana poduzeti s namjerom, odnosno krajnjim ciljem da takve radnje prouzrokuju kod djeteta, odnosano maloljetnika odavanje alkoholu i drugim oblicima asocijalnog ponašanja ili pak da je roditelj, usvojitelj, staratelj ili drugo lice u odnosu na kvalifikatornu okolnost, odnosno nastupanje teže posljedice iz člana 219. st. 3. KZ FBiH, koja se ogleda u odavanju djeteta, odnosno maloljetnika alkoholu i drugim oblicima asocijalnog ponašanja prouzrokovanih preduzimanjem radnji grubog zanemarivanja vaspitanja ili zbrinjavanja djeteta ili maloljetnika iz stava 1 ili opciono propisanih kvalifikatornih radnji iz stava 2 istog člana, postupao iz nehata.

7 Čl. 129. st. 4. KZ entiteta RS. U KZ entiteta RS ova inkriminacija ima drugi naziv „Navođenje na samoubistvo i pomaganje u samoubistvu“" 
ili zlostavljanje djeteta ili maloljetnika iz člana 219. st. 3. KZ FBiH. ${ }^{58} \mathrm{Na}$ taj način, radnje zanemarivanja ili zlostavljanja, kao oblici ovog djela, javljaju se kao produženi uzročni lanac brojnih negativnih pojava počev od asocijalnih i inkriminirajućih, pa do autodestruktivnih oblika ponašanja djeteta ili maloljetnika.

U krivičnim zakonodavstvima u $\mathrm{BiH}$, prisutna je različita kaznena politika, odnosno propisana je različita visine kazne u odnosu na kvalifikatornu okolnost koja se odnosi na odavanje djeteta ili maloljetnika alkoholu ili drugim oblicima asocijalnog ponašanja djeteta ili maloljetnika. Naime, $\mathrm{KZ} \mathrm{FBiH} \mathrm{i} \mathrm{KZ} \mathrm{BD} \mathrm{BiH}$, u odnosu na KZ RS, propisuju nižu mjeru kazne, odnosno niži posebni minimum i maksimum kazne za navedenu kvalifikatornu okolnost kod krivičnog djela „Zapuštanje ili zlostavljanje djeteta ili maloljetnika" tako da je za kvalifikatorni oblik djela iz čl. 219. st. 3. KZ FBiH i čl. 216. st. 3. KZ BD BiH koji se odnosi na odavanje djeteta ili maloljetnika alkoholu i drugim oblicima asocijalnog ponašanja propisana kazna zatvora od tri mjeseca do pet godina, dok je za istu kvalifikatornu okolnost iz člana 187. st. 3. KZ RS propisana stroža kazna, odnosno viši posebni minimum i maksimum kazne unutar opšteg zakonskog kaznenog okvira, tako da je propisana kazna zatvora od jedne do osam godina, čime se u krivičnom zakonodavstvu Republike Srpske, u pogledu kvalifikovanog oblika krivičnog djela „zapuštanje ili zlostavljanje djeteta“, kroz strožu kaznenu politiku zakonodavca, maloljetnim licima pruža jača krivičnopravna zaštita od alkoholizma, odnosno odavanja alkoholu u odnosu na krivično zakonodavstvo Federacije $\mathrm{BiH}$ i krivično zakonodavstvo Brčko distrikta $\mathrm{BiH}$.

\subsection{Prekršajnopravna zaštita maloljetnika od alkoholizma}

Prekršajnopravna zaštita maloljetnika od zloupotrebe alkohola u prekršajnom zakonodavstvu regulisana je odredbama Zakona o prekršajima protiv javnog reda i mira i ostvaruje se propisivanjem odredbe o odgovornosti, odnosno kažnjavanju lica za radnju posluživanja, odnosno prodaje alkoholnog pića maloljetnicima i odredbe o odgovornosti, odnosno kažnjavanju punoljetnog lica za radnju navođenja maloljetnika na uživanje, tj. konzumiranje alkohola, odnosno alkoholnog pića.

U pogledu prekršajnopravne odredbe koja se odnosi na propisivanje odgovornosti, odnosno kažnjavanje lica za radnju posluživanja ${ }^{59}$, odnosno prodaje alkoholnog pića maloljetnicima, za razliku od de lege lata krivičnopravne odredbe u krivičnom zakonodavstvu Federacije $\mathrm{BiH}$ koja se odnosi na posluživanje mlađih

58 Vid o tome: B. Cvjetko, M. Singer /2013/: op. cit., p. 315.

59 Posluživanje alkoholnih pića (mlađim) maloljetnicima u kaznenim zakonodavstvima entiteta FBiH i Brčko distriktu BiH je predmet i krivičnopravne i prekršajnopravne regulative. Razlika, odnosno granična linija izmedju krivične inkriminacije i prekršaja (prema Zakonu o prekršajima protiv javnog reda i mira), koji se odnosi na posluživanje maloljetnika alkoholnim pićem se ogleda u vrsti, odnosno količini posluženog alkoholnog pića. Naime, krivična inkriminacija „posluživanje mlađeg maloljetnika alkoholnim pićem“ se, prema krivičnopravnoj odredbi, vezuje za posluživanje žestokim alkoholnim pićem ili drugim alkoholnim pićem, odnosno alkoholnim pićem sa manjim procentom alkohola u količini koja može dovesti do stanja pijanstva, dok se u pogledu prekršaja radi isključivo o posluživanju alkoholnim pićem sa manjim procentom alkohola i to u neznatnoj, odnosno manjoj količini koja ne može dovesti do stanja pijanstva koje proizilazi iz radnje posluživanja alkoholnim pićem kod krivične inkriminacije. 
maloljetnika alkoholnim pićem, zabrana posluživanja, odnosno prodaje alkoholnog pića u prekršajnom zakonodavstvu se odnosi na maloljetnike, odnosno na kategoriju i mlađih i starijih maloljetnika. Jedino u prekršajnom zakonodavstvu Brčko distrikta $\mathrm{BiH}$ zabrana posluživanja alkoholnim pićem se odnosi, odnosno ograničena je na mlađe maloljetnike, tako da se, kao i u krivičnom zakonodavstvu, ne odnosi na obe kategorije maloljetnika. U vezi sa navedenim, u cilju harmonizacije prekršajnopravnih odredbi koje se odnose na dobnu granicu zabrane posluživanja maloljetnika alkoholnim pićem u prekršajnom zakonodavstvu u Bosni i Hercegovini, kao prijedlog de lege ferenda potrebna je izmjena prekršajne odredbe u Zakonu o javnom redu i miru Brčko distrikta $\mathrm{BiH}$, koja bi, kao i u ostalim prekršajnim zakonodavstvima, podrazumijevala proširivanje zabrane posluživanja alkoholnim pićem i na starije maloljetnike. ${ }^{60}$

U pogledu prekršajne odredbe koja se odnosi na posluživanje maloljetnika alkoholnim pićem, za postojanje prekršaja bitna je sama radnja posluživanja maloljetnika alkoholnim pićem kao obilježje bića ovog prekršajnog djela, uz postojanje svijesti kod prodavca da se alkoholnim pićem poslužuje maloljetnik.

Takođe, kada su u pitanju maloljetnici, postojanje ovog prekršaja nije uslovljeno narušavanjem javnog reda i mira od strane maloljetnika usljed posluživanja, odnosno prodaje alkoholnog pića ovoj uzrasnoj kategoriji lica i konzumiranja istog, tako da u pogledu ove kategorije lica zakonodavac ovaj prekršaj vezuje za samu radnju posluživanja alkoholnim pićem maloljetnika. Drugim riječima, zakonodavac sankcionira samu radnju posluživanja alkoholnim pićem ove kategorije lica.

Međutim, u odnosu na druge kategorije lica koja se pored maloljetnika navode u prekršajnoj odredbi, odnosno u odnosu na posluživanje alkoholnim pićem (očigledno) pijanih lica ${ }^{61}$ postojanje prekršaja je uslovljeno narušavanjem javnog reda i mira od strane istih lica, tako da samo posluživanje alkoholnim pićem očigledno pijanih lica ne predstavlja prekršaj ukoliko, usljed posluživanja alkoholnim pićem, nije došlo do narušavanja javnog reda i mira od strane tih lica. To, zapravo, znači da za postojanje ovog prekršaja mora postojati, odnosno biti utvrđena kauzalna povezanost između radnje posluživanja očigledno pijanih lica alkoholnim pićem i narušavanja javnog reda i mira od strane tih lica, tako da je radnja posluživanja alkoholnim pićem očigledno pijanih lica (i radnja konzumiranja posluženim alkoholnim pićem od strane očigledno pijanih lica) uzrokovala narušavanje javnog reda i mira od strane tih lica.

Zakonodavac je propisao odredbu o zabrani posluživanja maloljetnika alkoholnim pićem, pri čemu je prisutan problem oko načina realizacije, odnosno provodi-

60 S. Orlić, J. Krštenić, S. Karović /2019/: Sociopatološke zavisnosti i legislativni okviri zaštite mladih u Bosni i Hercegovini - sa osvrtom na stanje u Srbiji - de lege lata et de lege ferenda, Pravni život, br. 9/19, pp. 297-312.

61 Očigledno pijano lice ili lice pod očiglednim uticajem alkohola je lice u izrazito alkoholisanom stanju koje je već na prvi pogled uočljivo na osnovu njegovog ponašanja (nestabilnost pri stajanju, zaplitanje jezika, pomućenost vida, izazivanje na svađu i tuču, nepristojno ponašanje itd). Dakle, to bi u svakom slučaju bilo lice koje očiglednim ponašanjem pokazuje alkoholisanost koja ne predstavlja lakšu pripitost (vid. M. Tukar /2018/: Komentar Zakona o javnom redu i miru, drugo dopunjeno izdanje, Službeni glasnik, Beograd, p. 61). 
vosti ove odredbe. To se u praksi najčešče čini kroz obavezu zaposlenog osoblja da prilikom prodaje, odnosno posluživanja alkoholnim pićem u ugostiteljskoj ili nekoj drugoj radnji u kojoj se prodaju alkoholna pića provjerava identitet lica koja kupuju, odnosno poslužuju se alkoholnim pićem putem identifikacione isprave radi provere, odnosno utvrđivanja starosne dobi lica koja kupuju, odnosno poslužuju se alkoholnim pićem.

Ipak, u praksi se nailazi na propuste u pogledu provodivosti ove odredbe koji se ogleda u tome da se ove provjere starosne dobi lica koja kupuju, odnosno poslužuju se alkoholnim pićem uopšte ne vrše od strane zaposlenog osoblja ili ako se vrše ne postoji dosljednost i kontinuiranost $\mathrm{u}$ ovoj provjeri tako da danas imamo veliki broj mladih, uključujući i maloljetnike koji bez kontrole ulaze u objekte u kojima se toči, odnosno konzumira ili prodaje alkoholno piće što konsekventno tome dovodi do porasta učešča mladih u konzumiranju alkoholnog pića i odavanja alkoholu sa tendencijom stvaranja zavisnosti o istom i opasnosti od činjenja kaznenih djela maloljetnika pod uticajem ili usljed zavisnosti o alkoholu, odnosno alkoholnom piću.

Kada je u pitanju zloupotreba alkohola maloljetnika, u pogledu odredbi koje se odnose na prekršajnopravnu zaštitu maloljetnika od ove zloupotrebe, postoje razlike između prekršajnih zakonodavstava u Bosni i Hercegovini (kantonalnih Zakona o javnom redu i miru u FBiH i Zakona o JRM u RS i BD BiH).

Jedna od razlika se ogleda u pogledu druge odredbe kojom se ostvaruje prekršajnopravna zaštita mladih od zloupotrebe alkohola, odnosno u pogledu toga što prekršajna odredba iz Zakona o javnom redu i miru koja se odnosi na kažnjavanje lica za radnju navođenja maloljetnika na uživanje, odnosno konzumiranje alkoholnog pića, nije propisana u svim, već samo u nekim prekršajnim zakonodavstvima. ${ }^{62}$ $\mathrm{S}$ tim u vezi, kao prijedlog de lege ferenda, trebalo bi u pogledu ove vrste prekršaja ujednačiti prekršajnu legislativu tako da u svim prekršajnim zakonodavstvima, pored odredbe o propisivanju odgovornosti i kažnjavanju za radnju posluživanja ili prodaje alkoholnog pića maloljetnicima, bude propisana i prekršajna odredba $o$ propisivanju odgovornosti i kažnjavanju punoljetnog lica za radnju navođenja maloljetnika na uživanje, odnosno konzumiranje alkoholnog pića. kao kvalifikatorne okolnosti kod ovog prekršajnog djela s obzirom na starosnu dob pasivnog subjekta.

Ratio legis uvođenja, odnosno propisivanja ove odredbe u svim prekršajnim zakonodavstvima u Bosni i Hercegovini se ogleda u tome što je od svih asocijalnih pojava odavanje maloljetnika alkoholu, odnosno konzumiranje alkoholnog pića, uz narkomaniju, odnosno konzumiranje opojnih sredstava, najprevalentniji uzročnik prestupničkog ponašanja maloljetnika, uključujući i činjenje prekršajnih djela sa elementima nasilja. S tim u vezi, upravo iz tog razloga, propisivanje odredbe o odgovornosti, odnosno sankcionisanju punoljetnog lica za radnju navođenja maloljetnika na uživanje alkohola, odnosno alkoholnog pića, kao obilježja bića ovog prekršajnog djela, u prekršajnom zakonodavstvu dobija na posebnom značaju, te je

62 Ova odredba je sadržana samo u Zakonu o javnom redu i miru Republike Srpske (čl. 25. st. 1. ZKRM RS, Službeni glasnik RS, br. 11/15). Odgovorna lica za radnju navođenja maloljetnika na uživanje, tj. konzumiranje alkohola, odnosno alkoholnog pića pored prodavca ili poslužioca alkoholnim pićem, mogu biti i druga lica koja navode maloljetnika na kupovinu alkohola radi konzumiranja istog, ili pak na konzumiranje kupljenog alkohola od strane drugog lica. 
u funkciji suzbijanja, odnosno smanjenja konzumiranja alkoholnog pića od strane maloljetnih lica i uzrokovanja činjenja prekršajnih djela maloljetnika po navedenom osnovu.

Takođe, u pogledu prekršajnih odredbi koje se odnose na prekršajno-pravnu zaštitu maloljetnika od zloupotrebe alkohola prisutne su razlike, odnosno velika nesrazmjera između prekršajnih zakonodavstava u Bosni i Hercegovini i u pogledu kaznene politike, odnosno visine propisane novčane kazne za radnju posluživanja, odnosno prodaje alkoholnog pića maloljetnicima. Koliko je prisutna nesrazmjera, odnosno razlika u visini propisane novčane kazne za ovu vrstu prekršaja, odnosno za radnju posluživanja ili prodaje alkoholnog pića maloljetnicima, pokazuje odredba po kojoj maksimum propisane novčane kazne u jednom kantonu (300 KM u ZDK) za ovu vrstu prekršaja je manji od minimuma propisane kazne u drugom kantonu (od 400 do $1200 \mathrm{KM}$ u KS), ili u RS (od 400 do $1000 \mathrm{KM}$ ) i BD BiH (od 500 do $1500 \mathrm{KM}){ }^{63}$

U vezi sa navedenim, kao prijedlog de lege ferenda neophodno je izvršiti izmjene prekršajnih odredbi iz Zakona o javnom redu i miru u smislu usklađivanja odredbi o visini propisane novčane kazne za počinjeni prekršaj posluživanja, odnosno prodaje alkoholnog pića maloljetnicima prevashodno $\mathrm{u}$ onim kantonima $\mathrm{u}$ Federaciji $\mathrm{BiH}$ u kojima je propisan znatno manji minimum i maksimum propisane kazne sa odredbama iz Zakona o javnom redu i miru u kantonima sa većim minimumom i maksimumom propisane novčane kazne, kao i sa odredbama Zakona o javnom redu i miru RS i BD BiH. Ratio legis uvođenja ove izmene je što postojeća odredba o niskom minimalnom i maksimalnom iznosu novčane kazne u pojedinim kantonima (npr. ZDK) za počinjeni prekršaj posluživanja, odnosno prodaje alkoholnog pića maloljetnicima pogoduje porastu odavanja maloljetnika alkoholu, te porastu recidivizma, kao i primarnog prestupništva maloljetnika uzrokovanog konzumiranjem alkoholnog pića.

\section{ZAKLJUČNA RAZMATRANJA}

U današnjem vremenu maloljetna lica kao budućnost i osjetljiva kategorija društva izloženi su brojnim asocijalnim pojavama od kojih na svom značaju dobija zloupotreba alkohola i odavanje maloljetnih lica alkoholu koje poprima značajne razmjere među tom populacijom, te postaje jedan od glavnih izvora i uzročnik njihovog ulaska u svijet delinkvencije.

Pored preduzimanja brojnih preventivnih mjera usmjerenih na suzbijanju pojave zloupotrebe alkohola i odavanja maloljetnih lica alkoholu u kojima osnovni nosioci prevencije treba da budu porodica i vaspitno-obrazovne ustanove, poseban akcenat se daje i na legislativnim, odnosno kaznenopravnim aspektima zaštite maloljetnih lica od ovog oblika asocijalnog ponašanja mladih. Kaznenopravna zaštita mladih od zloupotrebe alkohola, odnosno odavanja alkoholu u Bosni i Hercegovini

63 Član 6. st. 3. ZJRM ZDK, Službene novine ZDK, br. 12/16, Član 8, st. 4. tač. a. ZJRM KS, Službene novine KS, br. 17/08, Član 25. st. 1. ZJRM RS, Službeni Glasnik RS br. 11/15, Član 13. st. 1. ZJRM BD BiH, Službeni Glasnik BD BiH, br. 14/10. 
se ostvaruje putem krivičnopravne regultative prema odredbama krivičnog zakona i putem prekršajnopravne regulative prema odredbama Zakona o prekršajima protiv javnog reda i mira.

$\mathrm{U}$ pogledu kaznenopravne zaštite maloljetnih lica od zloupotrebe alkohola $\mathrm{u}$ Bosni i Hercegovini evidentno je da su postojeća zakonska rješenja u krivičnom i prekršajnom zakonodavstvu dosta manjkava i neujednačena, te kao takva ne pružaju adekvatan okvir zaštite maloljetnih lica od zloupotrebe, odnosno odavanja alkoholu. U tom smislu, neophodno je izvršiti određene izmjene kako u krivičnom tako i u prekršajnom zakonodavstvu u pravcu unapređenja postojećih rješenja, te pružanja adekvatnijeg legislativnog okvira za bolju i efikasniju zaštitu maloljetnih lica od zloupotrebe alkohola.

U okviru krivičnog zakonodavstva prijedlog de lege ferenda je da se izvrši modifikacija u postojećoj inkriminaciji u krivičnom zakonodavstvu Federacije $\mathrm{BiH}$ i Brčko distrikta BiH. Ta modifikacija podrazumijeva uvođenje u krivično zakonodavstvo veće dobne granice zabrane posluživanja maloljetnika alkoholnim pićem, odnosno proširivanje krivičnopravne zaštite od zloupotrebe alkohola i odavanja alkoholu propisivanjem u ovoj inkriminaciji zabrane posluživanja alkoholnim pićem i na kategoriju starijih maloljetnika. To bi značilo izmjenu u nazivu postojeće inkriminacije "služenje alkoholnih pića mlađim maloljetnicima“ i propisivanje izmjenjene inkriminacije pod nazivom „služenje alkoholnih pića maloljetnicima“, što podrazumijeva zabranu posluživanja alkoholnim pićem za obe uzrasne kategorije maloljetnika

Ratio legis izmjene naziva ove inkriminacije i proširivanja krivičnopravne zaštite, $u$ vidu propisivanja zabrane posluživanja alkoholnih pića, i na kategoriju starijih maloljetnika je višestruke prirode, pri čemu preovladavaju zdravstveni i kriminalnopolitički razlozi. Naime, s jedne strane, svi razlozi zdravstvene prirode koji opravdavaju zabranu posluživanja alkoholnih pića mlađim maloljetnicima i ogledaju se $\mathrm{u}$ štetnom uticaju alkohola na zdravlje ovu kategorije maloljetnika mogu se uzeti u obzir i kada su u pitanju stariji maloljetnici jer se i kod ove kategorije maloljetnika, zbog postojeće osjetljivosti njihovog organizma na alkohol, reflektuje štetan uticaj alkohola na njihovo zdravlje i psihofizički razvoj u istoj mjeri u kojoj se to odražava na mlađe maloljetnike, tako da se štetno dejstvo alkohola jednako reflektuje na obe kategorije maloljetnika.

Pored toga, jedan od razloga zdravstvene prirode povezan i sa kriminalnopolitičkim razlozima je i taj što do širenja zloupotrebe alkohola, odnosno konzumiranja alkoholnog pića i odavanja maloljetnika alkoholu, kao i sticanja zavisnosti o alkoholu među najmlađim članovima društva dolazi upravo u ovoj dobi usljed čestog konzumiranja alkoholnih pića ove kategorije lica.

Posljedično tome, na navedene zdravstvene razloge o opravdanosti propisivanja ove inkriminacije i proširivanja krivičnopravne zaštite, u vidu propisivanja zabrane posluživanja alkoholnih pića, i na kategoriju starijih maloljetnika, naslanjaju se i kriminalnopolitički razlozi koji se ogledaju u tome što je kod starijih maloljetnika, usljed raširenosti konzumiranja alkoholnog pića u ovoj uzrasnoj dobi, najizraženiji maloljetnički recidivizam pri čemu je u najvećoj mjeri prisutna incidenca činjenja 
brojnih inkriminirajućih radnji pod uticajem alkohola, kao i usljed odavanja alkoholu i prerano stečene zavisnosti o istom, tako da danas imamo sve veći broj starijih maloljetnika koji konzumirajući alkohol i pod njegovim odlučujućim uticajem, ili usljed zavisnosti o istom, čine krivična, kao i prekršajna djela sa elementima nasilja.

Takođe, uz zdravstvene i kriminalnopolitičke razloge, ratio legis izmjene ove inkriminacije u krivičnom zakonodavstvu $\mathrm{FBiH}$ je i normativne prirode i ogleda se u potrebi harmonizacije krivičnih i prekršajnih odredbi koje se odnose na posluživanje alkoholnim pićem maloljetnika, odnosno lica od 14 do 18 godina, jer se u prekršajnom zakonodavstvu na nivou kantona u $\mathrm{FBiH}$, kao i u prekršajnom zakonodavstvu Republike Srpske, prema Zakonu o prekršajima protiv javnog reda i mira, kao prekršaj smatra posluživanje alkoholnim pićem maloljetnika, odnosno i mlađih i starijih maloletnika.

Pored navedenog, potrebno je i usklađivanje kaznene politike u krivičnim zakonodavstvima u Bosni i Hercegovini u pogledu inkriminacije, odnosno kvalifikatorne odredbe koja se odnosi na odavanja maloljetnog lica alkoholu tako da se ujednači visina kazne, odnosno propiše jednak posebni minimum i maksimum kazne unutar opšteg kaznenog okvira za kvalifikatornu okolnost kod krivičnog djela „Zapuštanje ili zlostavljanje djeteta ili maloljetnika“ koja se odnosi na odavanje maloljetnika alkoholu, na način da se i u krivičnom zakonodavstvu Federacije BiH i Brčko distrikta $\mathrm{BiH}$ propiše viši posebni minimum i maksimum kazne zatvora, odnosno da bude isti kao u krivičnom zakonodavstvu Republike Srpske i iznosi od jedne do osam godina, kako bi se time maloljetnim licima pružila jača krivičnopravna zaštita od odavanja alkoholu i drugih oblika asocijalnog ponašanja uzrokovanog radnjama grubog zanemarivanja zbrinjavanja i vaspitanja djeteta ili maloljetnika iz člana 219. stav. $1 \mathrm{KZ}$ Federacije $\mathrm{BiH}$ i opciono propisanim kvalifikatornim radnjama zlostavljanja iz stava 2 istog člana, počinjenim od strane roditelja, usvojitelja, staratelja ili drugog lica.

U cilju harmonizacije prekršajnopravnih odredbi koje se odnose na dobnu granicu zabrane posluživanja maloljetnika alkoholnim pićem u prekršajnom zakonodavstvu u Bosni i Hercegovini potrebna je izmjena prekršajne odredbe u Zakonu o javnom redu i miru Brčko distrikta $\mathrm{BiH}$, koja bi, kao i u ostalim prekršajnim zakonodavstvima, podrazumijevala pružanje prekršajnopravne zaštite, u vidu propisivanja zabrane posluživanja alkoholnim pićem, i za starije maloljetnike, tako da bi ova zabrana posluživanja maloljetnika alkoholnim pićem obuhvatala obe dobne kategorije maloljetnika.

Takođe, potrebno je i propisivanje prekršajne odredbe o odgovornosti i kažnjavanju punoljetnog lica za radnju navođenja maloljetnika na uživanje, odnosno konzumiranje alkoholnog pića, kao kvalifikatorne okolnosti kod ovog prekršajnog djela s obzirom na starosnu dob pasivnog subjekta.

Ratio legis uvođenja, odnosno propisivanja ove odredbe u svim prekršajnim zakonodavstvima u Bosni i Hercegovini se ogleda u tome što je alkoholizam, odnosno konzumiranje alkoholnog pića od strane maloljetnika, uz narkomaniju, odnosno konzumiranje opojnih sredstava, najprevalentniji uzročnik prestupničkog ponašanja maloljetnika, uključujući i činjenje prekršajnih djela sa elementima nasilja. 
Zbog velike nesrazmjere između prekršajnih zakonodavstava u Bosni i Hercegovini u visini propisane novčane kazne u pogledu odredbe za počinjeni prekršaj posluživanja, odnosno prodaje alkoholnih pića maloljetnicima, neophodno je izvršiti izmjene prekršajnih odredbi iz Zakona o javnom redu i miru u smislu usklađivanja odredbi o visini propisane novčane kazne za navedeni prekršaj prevashodno u onim kantonima u Federaciji BiH u kojima je propisan znatno manji minimum kao i maksimum propisane kazne sa odredbama iz Zakona o javnom redu i miru u kantonima sa većim minimumom i maksimumom propisane novčane kazne, kao i sa odredbama Zakona o javnom redu i miru entiteta RS i BD BiH

Prezentirani prijedlozi de lege ferenda, odnosno prijedlozi izmjena aktuelne kaznenopravne legislative koje se odnose na zloupotrebu i odavanje maloljetnih lica alkoholu nesumnjivo su potrebne, odnosno neophodne u kaznenom zakonodavstvu u Bosni i Hercegovini, jer su u funkciji poboljšanja kaznenopravne zaštite maloljetnih lica od zloupotrebe alkohola i usmjerene na sprečavanje činjenja kaznenih djela maloljetnika pod uticajem alkohola, odnosno djela uzrokovanih konzumiranjem alkoholnog pića maloljetnih lica.

Međutim, i pored toga što se kaznenopravnom regulativom u značajnoj mjeri poboljšava, te, sa izmjenama zakonskih rješenja, jača i postiže efikasnija zaštita maloljetnih lica od zloupotrebe i odavanja alkoholu, kaznenopravnom regulativom se ne može postići sveobuhvatna i potpuna zaštita maloljetnika od zloupotrebe alkohola. Razlog za to se ogleda u tome što je zaštita maloljetnih lica od konzumiranja alkoholnog pića i odavanja alkoholu putem kaznenopravne regulative usmjerena pretežno ili najvećim djelom na suzbijanje neposrednog konzumiranja alkoholnog pića maloljetnih lica, odnosno neposrednog načina dolaska ili pristupa maloljetnih lica alkoholnom piću i njegovom konzumiranju, te na suzbijanje prestupničkog ponašanja maloljetnika koje je proisteklo, odnosno rezultiralo iz ovog vida konzumiranja alkoholnog pića od strane maloljetnih lica.

U vezi navedenog, razlog nepotpune zaštite maloljetnih lica od zloupotrebe alkohola, odnosno konzumiranja alkoholnog pića i odavanja alkoholu putem kaznenopravne regulative je u tome što je danas znatno izražen problem činjenja kaznenih djela maloljetnih lica uzrokovanih, odnosno proisteklih iz posrednog načina njihovog konzumiranja alkoholnog pića, odnosno posrednog načina dolaska ili pristupa maloljetnih lica alkoholnom piću i konzumiranju istog (npr. konzumiranje alkoholnog pića maloljetnika kupljenog od strane starijih lica, pri čemu se najčešče radi o konzumiranju alkoholnog pića maloljetnika na privatnim zabavama i u stanovima). Takav način konzumiranja alkoholnog pića maloljetnih lica i uzročno-posljedična povezanost sa njihovim prestupničkim ponašanjem je izvan domašaja legislative, odnosno kaznenopravne regulative. $\mathrm{U}$ tom smislu, pored kaznenopravnih, legislativnih, aspekata zaštite maloljetnih lica od zloupotrebe alkohola, potrebno je aktivnije djelovanje i drugih subjekata, odnosno nosilaca (porodice, škola i druge vaspitnoobrazovne ustanove itd.) prevencije zloupotrebe alkohola maloljetnih lica, kako bi se postigli sveobuhvatniji efekti na suzbijanju zloupotrebe alkohola, odnosno konzumiranja alkoholnog pića i odavanja maloljetnih lica alkoholu, kao i suzbijanju njihovog prestupničkog ponašanja uzrokovanog ovim vidom asocijalnog ponašanja. 


\section{LITERATURA}

Babić M., Filipović Lj., Marković I., Rajić Z. /2005/: Komentari krivičnih/kaznenih zakona u Bosni i Hercegovini - Knjiga 2, Savjet/Vijeće Evrope: Evropska komisija, Sarajevo.

Babić M., Marković I. /2018/: Krivično pravo - posebni dio, Pravni fakultet, Banja Luka.

Cvjetko B., Singer, M. /2013/: Kaznenopravna zaštita djece, Globus, Zagreb.

Hasić J. /2017/: Odnos kvaliteta života i delinkventnog ponašanja maloljetnika, Neobjavljeni magistarski rad, Islamski Pedagoški fakultet, Zenica.

Horović S. /2000/: Kazneno pravo - posebni dio, Pravni fakultet Sveučilišta u Mostaru.

Horović S. /2010/: Posebni dio kaznenog prava Bosne i Hercegovine - Knjiga II, Pravni fakultet Sveučilišta u Mostaru.

Išpanović-Radojković B., Ignjatović T. /2011/: Zaštita dece od zlostavljanja i zanemarivanja, Centar za prava deteta, Beograd.

Jovanović P., Čurčić S., Milosavčević V. /2000/: Prilog definiciji alkoholizma, dostupno na: https://scindex-clanci.ceon.rs/data/pdf/0350-2538/2000/0350-25380002105J. pdf\#search=\%22prilog\%20definiciji\%20alkoholizma\%22.

Jovanović,Lj. /1983/: Krivično pravo - posebni deo, Beograd.

Kapetanović-Bunar E. /1985/: Alkoholizam - život na dva kolosijeka, Globus, Zagreb.

Karić N. /2017/: Socijalni rad i maloljetnička delinkvencija u zajednici, OFF-SET, Tuzla.

Loga S. /1999/: Sudska psihopatologija, Fakultet kriminalističkih nauka, Sarajevo.

Mrvić-Petrović N. /2019/: Krivično pravo - posebni deo, Službeni glasnik, Beograd.

Munjiza M. /2017/: Psihopatologija svakodnevnog života, Vodič za zdrave i bolesne, za roditelje i njihovu decu, Treće izdanje, Službeni Glasnik, Beograd.

Nikolić Z., Joksić I. /2011/: Maloletnička delinkvencija - socijalnopsihološki i krivičnopravni aspekti, Institut za kriminološka i sociološka istraživanja, Beograd.

Orlić S., Krštenić J. i Karović S. /2019/: Sociopatološke zavisnosti i legislativni okviri zaštite mladih u Bosni i Hercegovini sa osvrtom na stanje u Srbiji - De lege lata et de lege ferenda, Pravni život, br. 9/19, Beograd.

Rajić Z., Tomić M., Miljko Z. /2000/: Komentar Kaznenog zakona Federacije Bosne i Hercegovine (Posebni dio), OSCE - Ured za demokratizaciju, Mostar.

Rutter M., Giller H., Hagell A. /1998/: Antisocial Behavior by Young People, Cambridge University Press, New York.

Stojanović Z. /2019/: Komentar Krivičnog zakona zakonika, deveto izmenjeno i dopunjeno izdanje, Službeni glasnik, Beograd.

Stojanović Z., Delić N. /2019/: Krivično pravo - posebni deo, Pravna knjiga, Beograd.

Šarić H. /2008/: Prostitucija i ostali oblici socijalne patologije, OFF.SET, Tuzla.

Tomić Z. /2003/: Krivično pravo - posebni dio, Magistrat, Sarajevo.

Tomić Z. /2007/: Krivično pravo - posebni dio, Pravni fakultet, Sarajevo.

Tukar M. /2018/: Komentar Zakona o javnom redu i miru, drugo dopunjeno izdanje, Službeni glasnik, Beograd.

\section{PROPISI}

Krivični zakon Federacije Bosne i Hercegovine (Službene novine FBiH br. 75/17).

Krivični zakon Republike Srpske (Službeni glasnik RS, br. 64/17, 104/18. odluka US)

Krivični zakon Brčko distrikta Bosne i Hercegovine (Službeni glasnik BD BiH, br. 50/18) 
Zakon o javnom redu i miru Republike Srpske (Službeni glasnik RS, br. 11/15)

Zakon o javnom redu i miru Brčko distrikta Bosne i Hercegovine (Službeni glasnik BD BiH, br. $14 / 10)$

Zakon o javnom redu i miru Zeničko-dobojskog kantona (SN ZDK, br. 12/16)

Zakon o javnom redu i miru Kantona Sarajevo (Službene novine KS, br. 17/08)

\section{Suad Orlić* \\ University of Zenica}

Sadmir Karović**

Faculty of Law, University of Travnik

\section{CRIMINAL PROTECTION OF YOUNG PEOPLE FROM ALCOHOLISM IN BOSNIA AND HERZEGOVINA}

\section{SUMMARY}

Alcoholism or alcohol abuse and indulgence in alcohol is one of the most prevalent antisocial phenomena in young people and one of the main causes of their criminal behavior. Namely, there is an increasing tendency for young people to abuse and consume alcohol and to indulge in alcohol frequently as well as the incidence of committing criminal offenses by young people under the decisive influence of alcohol. The paper elaborates the criminal law aspects of protecting young people from alcoholism or alcohol abuse and points out problem of uneven and inadequate legislation in Bosnia and Herzegovina, and gives appropriate proposals for changes to existing solution in order to achieve better and more effective criminal law protection of young people from alcohol abuse.

Key words: criminal law protection, misdemeanor protection, alcoholism, alcohol abuse.

\footnotetext{
* Assistant Professor, employed at the Ministry of Internal Affairs, Zenica-Doboj canton, suad. orlic@gmail.com

* Associate Professor, employed at the State Agency for Investigations and Protection, Bosnia and Herzegovina, karovic.s@hotmail.com
} 